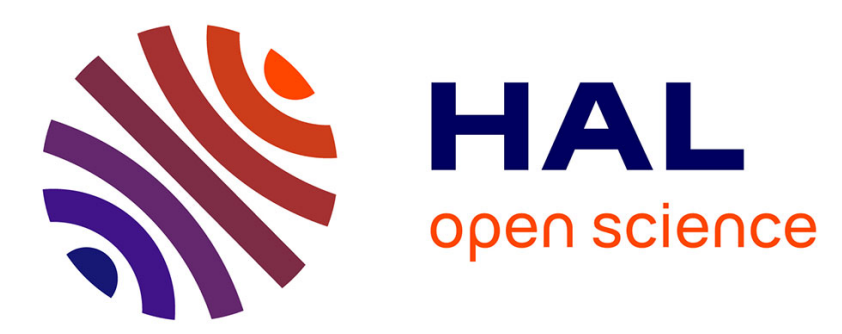

\title{
Quantifying the impact of no-till on sediment yield in southern Brazil at the hillslope and catchment scales
}

A. Londero, J. Minella, F. Schneider, D. Deuschle, O. Evrard, M. Boeni, G. Merten

\section{- To cite this version:}

A. Londero, J. Minella, F. Schneider, D. Deuschle, O. Evrard, et al.. Quantifying the impact of no-till on sediment yield in southern Brazil at the hillslope and catchment scales. Hydrological Processes, 2021, 35, pp.e14286. 10.1002/hyp.14286 . hal-03273746

\author{
HAL Id: hal-03273746 \\ https://hal.science/hal-03273746
}

Submitted on 16 Jul 2021

HAL is a multi-disciplinary open access archive for the deposit and dissemination of scientific research documents, whether they are published or not. The documents may come from teaching and research institutions in France or abroad, or from public or private research centers.
L'archive ouverte pluridisciplinaire HAL, est destinée au dépôt et à la diffusion de documents scientifiques de niveau recherche, publiés ou non, émanant des établissements d'enseignement et de recherche français ou étrangers, des laboratoires publics ou privés. 
1 Title: Quantifying the impact of no-till on runoff in southern Brazil at hillslope and catchment

2 scales

Keywords: hydrological monitoring, soil management, soil conservation, curve number, infiltration, terraces, water losses.

\section{Abstract:}

No-till (NT) is a conservation system that improves the hydrological regime of agricultural slopes by providing greater surface protection and benefits to the physical and hydrological properties of soils. However, the isolated use of NT is not enough to control runoff and its associated degradation processes. Therefore, this study aimed to evaluate the runoff of agricultural slopes under NT under different runoff control conditions by monitoring 63 rainfall events in two 2.4-ha zero-order catchments and 27 rainfall events in four 0.6-ha macroplots. The catchments are paired and similar in terms of the type of soil and relief, but different regarding the presence of terraces. The macroplots have different soil and crop management systems. By using monitoring techniques, the hyetographs and hydrographs revealed the influence of the different types of management on the catchments and macroplots and allowed rainfall characteristics, runoff volume, runoff coefficients, water infiltration, peak runoff, response times, and curve number to be analyzed. The terraces positively affected the NT and controlled runoff and related variables, in addition to infiltration significantly increasing and runoff reducing in the terraced catchment. All the hydrological information assessed pointed to the positive effects provided by the presence of the terraces. The results in the macroplots showed that high amounts of phytomass and/or chiseling do not control runoff and its correlated variables in medium and high magnitude events. The study concludes by underlining the need for additional measures to control runoff (terraces), even in areas under NT and with high phytomass production. Additionally, the study emphasizes the importance of monitoring at the catchment scale to better understand the hydrological behavior of agricultural areas and provide the necessary parameters to effectively control runoff.

\section{1. Introduction}


Soil conservation in Brazil made a breakthrough in the 1990s with the spread of no-till (NT). This practice of soil conservation is based on several key principles, such as not tilling the soil, maintaining plant residues on the soil, and controlling runoff (Derpsch, Friedrich, Kassam, \& Hongwen., 2010; Friedrich, Derpsch, \& Kassam, 2012; Reicosky, 2015). Despite the widespread adoption of NT in Brazil, the quality of the system falls short in mitigating problems of conservation and environmental nature. Moreover, disregard is given to the full adoption of technological processes required by the conservation system (Didoné et al., 2014;

54 Ribeiro et al., 2014; Le Gall et al., 2017; Londero et al., 2017; Tiecher et al., 2017a; Deuschle,

55 Minella, Hörbe, Londero, \& Schneider, 2019). Simplifying the system as a conservation

56 strategy through the sole use of NT is not enough to maintain or improve soil quality and control runoff and erosion processes (Friedrich et al., 2012; Olley, Brooks, Spencer, Pietsch, \&

58 Borombovits, 2013; Reicosky, 2015), leading to negative repercussions in production, the environment, and society.

Furthermore, overlooking soil conservation practices further aggravates problems caused by climate change and high volume and intensity rains, and this hydrological and erosive standard must be understood through a monitoring approach capable of reflecting the dominant hydrological processes. Therefore, studies on runoff formation and propagation on agricultural slopes and paired catchments are fundamental to define the best control strategy (Williams, Wuest, \& Long, 2014; Merten, Araújo, Biscaia, Barbosa, \& Conte, 2015; Sidle, 2018). Hydrological monitoring data is essential to better comprehend how agricultural activity affects water flow on the landscape (Merten et al., 2015; Londero et al., 2017; Deuschle et al., 2019).

68 In addition, hydrological and sedimentological monitoring data serve as a basis for calibrating 69 and validating mathematical models, which are useful to simulate conservation scenarios and their effects on soil and water resource degradation (de Vente et al., 2013). The spatial and

71 temporal distribution of rainfall is significantly affected by climate change (IPCC, 2013;

72 Delgado et al., 2011). In southern Brazil, more erosive rainfall is projected to occur (Almagro,

73 Oliveira, Nearing, \& Hagemann, 2017), which corresponds to a new standard of rainfall with

74 higher frequency, intensity, and accumulated volume, in addition to longer and more severe droughts (IPCC, 2013). These factors negatively affect the agricultural activity and water resources, and small changes in rainfall patterns directly impact crop productivity and the geography of production, thus jeopardizing agricultural development and food security in numerous regions. Given this scenario, the agricultural system must adapt to this new rainfall pattern and conditions of water deficit or excess by maximizing infiltration and controlling runoff. Basche (2017) and Rockstrom et al. (2010) described the need to manage water in agricultural systems to minimize the economic and environmental effects of floods and droughts. Moreover, the demand for food will require a $60 \%$ increment in production in the following decades, increasing agricultural water consumption by $40 \%$ (FAO, 2015). Nevertheless, this rise in water use can be mitigated by avoiding waste due to runoff.

One commonly employed water management technique in agricultural areas is terracing, which consists of using strips of land mobilized at a level to intercept runoff and reduce its 88 Castroviejo, 2015; Hussein, Amien, \& Kariem, 2016). With the spread of NT and its benefits 89 
90 founded justifications at the end of the 1990s (Caviglione et al., 2010). The abandonment of terracing occurred due to changes in the technological standards of grain production in Brazil (larger agricultural properties, genetic engineering, and developments in the agricultural machinery and equipment sector), erroneously implying this technique would be unnecessary and reduce the efficiency of agricultural operations. Allied to this, the excessive use of

95

96

97

98

99

100

101

102

103

104

105

106

107

108

109

110

111

112

113

114

115

116

117

118

119

120

121

122

123

124

125

126

127

128

129

130 agricultural machinery in conditions that were often inadequate significantly increased the problems of soil compaction, including reduced soil water infiltration and storage (Alaoui, Rogger, Peth, \& Blöschl, 2018, NRCS, 2004).

Estimating runoff is pivotal in soil and environment conservation practices, such as using the Curve Number method (CN) (Hawkins, Ward, Woodward, \& Van Mullem, 2009; Mishra, Tyagi, Singh, \& Singh, 2006). Runoff volume is estimated from rainfall volume and $\mathrm{CN}$ values, which must be obtained from a set of monitored events in which rainfall and runoff are considered. Despite the importance and versatility of the $\mathrm{CN}$ method, few studies have been conducted in Brazil (Oliveira et al., 2016; Pruski, Griebeler, \& Silva, 2001; Tedela et al., 2013; Do Valle Junior, Rodrigues, \& de Oliveira, 2019) to estimate $C N$ values under Brazilian conditions, and the correct parameterization of the $\mathrm{CN}$ is essential for validating the method for application under different conditions. The surface and subsurface conditions of the NT carried out in Brazil are very particular that must be adapted in hydrological and erosive modeling (Huang, Gallichand, \& Zhang, 2003; Polyakov et al., 2010).

The analysis of hydrological responses as a function of soil use and management can be performed by comparing hydrographs in paired catchments (Rinaldo, Vogel, Rigon, and Rodriguez-Iturbe, 1995; Nadal-Romero, Peña-Angulo, \& Regüés, 2018; Williams et al., 2014; Solyom and Tucker; 2004). In NT, geomorphology control is crucial since erosive processes are concentrated in the thalweg, and there is a great demand for information on the effects of different conservationist management practices on controlling runoff at catchment scale. This data is essential for choosing the best set of practices, considering farmers' interests and need to protect water resources. In this context, this study aimed to evaluate the hydrological variables obtained through the hydrological monitoring of catchments and paired slopes under NT to evidence the effects of the farming practices on runoff. The objective was to generate information from hyetographs and hydrographs capable of quantitatively demonstrating the efficiency of the amount of biomass, chiseling, and terracing in reducing runoff.

\section{Materials and Methods}

The study is based on the monitoring of rainfall and liquid discharge representing the volume of runoff in two zero-order catchments and four paired macroplots. These monitoring units represent different surface conditions in NT. The information extracted from the events was used to characterize the runoff in each of the studied conditions. Monitoring was performed between 2014 and 2018 in southern Brazil (29 $\left.13^{\prime} 39^{\prime \prime} \mathrm{S}, 53^{\circ} 40^{\prime} 38^{\prime \prime} \mathrm{W}\right)$ in a region belonging to the Southern Plateau, which was formed from successive volcanic spills with the formation of 
131 extrusive volcanic rocks (Figure 1) and characterized by a smooth wavy relief and 5-13\% 132 slopes. The region has a Cfa climate (humid subtropical) with hot and humid summers and dry 133 and cold winters, according to the Köppen classification (Alvares, Stape, Sentelhas, De Moraes 134 Gonçalves, \& Sparovek, 2013). The soil has $>30 \%$ of clay content and is classified as Rhodic 135 Nitisol (Dystric) (WRB, 2014). The average annual rainfall is $1678 \mathrm{~mm}$, evenly distributed 136 throughout the year.

137

138 139

Figure 1. Location of the experimental area and six monitoring units.

The six monitoring units were placed side by side on a slope with similar soil and relief characteristics and representative of the physiographic conditions of the region. A previous physical and chemical soil characterization of the slope demonstrated the homogeneity of the area (Deuschle et al., 2019; Londero et al., 2016). A detailed topographic survey and analysis of topographic attributes of the slope, slope shape, accumulated runoff, and moisture content of the terrain were then performed using the digital elevation model (DEM). These indices were used to define the monitoring units. Different sizes, positions, and directions of the units were tested to seek the maximum similarity. Homogeneity was considered within the units and between them.

Two different scales were used considering the area of contribution and form. One of them was the hydrographic catchment with the largest contribution area and converging curvature in the plane and a length slope of $\sim 200 \mathrm{~m}$ to evaluate the runoff control management (broad-based terraces). The other scale explored was the slope scale with the smallest contribution area with rectilinear curvature in the plane and length slope of $\sim 80 \mathrm{~m}$ to assess the influence of soil and crop management.

\subsection{Zero-order catchments and macroplots}

The two zero-order catchments are paired and have similar soil and relief characteristics. The catchments were named non-terraced catchment (NTC) and terraced catchment (TC) with 2.43 and 2.35 ha, respectively, with approximately $200 \mathrm{~m}$ in length, converging curvature in the plane, and convex in the profile favoring the concentration and spread of runoff. Small ridges (40 $\mathrm{cm}$ high) were built to delimitate the experimental units and prevent runoff from coming in from outside of the catchment. Five medium-level infiltration terraces were built at the TC. The terraces were distributed and dimensioned according to the estimated runoff volume for a design rainfall of $110 \mathrm{~mm}$ based on a ten-year return period (RP) for $6 \mathrm{~h}$ of duration. The basic infiltration velocity is measured in concentric rings in the order of $20 \mathrm{~mm}$ $\mathrm{h}^{-1}$. The terraces are 40-70 $\mathrm{cm}$ high, have $\sim 2 \mathrm{~m}^{2}$ cross-sectional areas, and were built with their ends closed to prevent water from leaving the system and enable total runoff quantification (Figure 2).

Figure 2. The terraces controlling the runoff after a rainfall event. 
The crops intended for grain production and soil cover were the same for both catchments in all monitoring years. In the first three years (2014-2016), a lower addition of phytomass was applied using soybean (Glycine max), wheat (Triticum spp.), and black oats (Avena sativa L.). In the following two years (2017-2018), there was a greater addition of phytomass using maize (Zea mays L.), black oats (Avena sativa L.), and forage turnip (Raphanus raphanistrum L.). The average production of phytomass was $3.0 \mathrm{t} \mathrm{ha}^{-1}$ during the period of cropping the binomial soybean/wheat or soybean/black oats. In the period of the greatest phytomass addition, the forage turnip ensured approximately $4.0 \mathrm{t} \mathrm{ha}^{-1}$ and maize approximately $12.0 \mathrm{t} \mathrm{ha}^{-1}$.

The four paired macroplots M1, M2, M3, and M4 have 0.59, 0.60, 0.63, and 0.63 ha, respectively, and $8.8,9.0,9.2$, and $8.8 \%$ slopes with straight curvature in the plane and slightly convex in the profile. The average ramp length is $80 \mathrm{~m}$ and enough for runoff formation without forming an ephemeral channel, which is different from what happens in the zero-order catchments. Thus, the flow spreads in relatively parallel flow lines towards the monitoring section. Ridges prevent water from entering and leaving the macroplots. Soil (no-till and chiseling) and plant (crop rotation) management practices were carried out to assess their ability to control runoff without the need to adopt terraces. All macroplots were cultivated under NT, two (M1 and M3) with chiseling (C), and two (M2 and M4) without chiseling (NC). Chiseling was performed in the first year of monitoring after the summer harvesting.

Chiseling is a commonly used tillage process to increase infiltration and reduce runoff. The other treatment tested was the amount of phytomass added to the soil through the chosen crops. There was a low addition of phytomass (LF) with soybean, fallow, and wheat succession in M1 and M2 and a high addition of phytomass (HF) with soybean or corn, turnip, oats, vetch, or wheat succession in M3 and M4. Contour farming was carried out as a standard practice in all monitoring units. Table 1 shows the nomenclature of treatments adopted in both catchments and four macroplots.

Table 1. Soil, plant, and water management systems (treatments) used in each catchment and macroplot.

\subsection{Monitoring and hydrological analysis}

Hydrological monitoring of rainfall (P) and runoff (Q) was carried out from July 2014 to April 2018 in the zero-order catchments and from July 2015 to April 2018 in the macroplots during rainfall-runoff events (runoff depth $>0.1 \mathrm{~mm}$ ). All monitored events were overseen by a field team that manually recorded water level height variations and collected water samples to assess water quality and suspended sediment concentration. Rainfall was monitored with a rain gauge programmed to record data at two-minute intervals and two rain gauges to quantify the daily accumulated rainfall. The rainfall gauge was installed in the outlet of NTC and flow data was obtained by monitoring the water level measured in $\mathrm{H}$-flumes using a staff gauge and pressure transducer sensors (Campbell brand) with a precision of five millimeters and five- 
215 minute intervals. In addition, 3-meter long soothing channels were installed upstream of the H216 flumes to ensure runoff flow linearity (Figure 3). The flumes were scaled based on the 217 maximum runoff estimate using the rational method (Chevallier, 1991).

219 Figure 3. H-flume for monitoring the flow rates installed in the lower part of the catchments and macroplots.

The relationship between the elevation and flow is defined using a specific rating curve depending on the dimensions of the installed flumes (Brakenseik et al., 1979). The flumes in the zero-order catchments were $0.6096 \mathrm{~m}$ wide and $0.4572 \mathrm{~m}$ wide in the macroplots. Each event featured a specific condition (catchments or macroplots) and was unique in terms of climatic characteristics (rainfall and soil moisture) and surface conditions (crop development stage and management effects). Hydrologic characteristic variables were extracted from hyetographs and hydrographs for each event with the potential of reflecting the effects of these factors on runoff behavior (formation and propagation). The data were analyzed to characterize the differences between the management systems in each monitoring unit. Three complementary approaches were used to analyze data and indicate differences between monitoring units:

a) Characteristic variables derived from hydrographs and hyetographs such as runoff depth (mm), runoff coefficient (\%), peak flow $\left(\mathrm{L} \mathrm{s}^{-1}\right)$, lag times (min), etc.;

b) Estimation of apparent infiltration based on instantaneous data of runoff and rainfall intensity; and

c) Estimation and analysis of the "Curve Number" $(\mathrm{CN})$ parameter integrating the main controlling factors.

\section{a) Hydrological characteristics}

256 Table 2. Characteristic variables obtained in the hyetogram and hydrogram analysis.

Hyetographs and hydrographs were analyzed to obtain characteristic variables sensitive to the influence of controlling factors (climate, crop management, and soil management). As the monitoring units are paired, each rainfall event generates a response capable of quantitatively indicating the efficiency of the management in controlling runoff by reducing its volume and peak flow $\left(\mathrm{Q}_{\text {peak }}\right)$. Therefore, we sought information from the hyetograph and hydrograph that characterize the event and express the influence of the surface condition in each monitoring unit influenced by the imposed management and characteristics of the rainfall that occurred. The set of all variables analyzed are shown in Table 2 and divided into four categories: a) rainfall, b) runoff, c) rainfall-runoff relationship, and d) lag time. Information on lag time was obtained based on the method proposed by Dingman (2015). The values are presented using box plot graphs that show the median (middle line), first and quartile (box), maximum and minimum values (whiskers), and extreme values (points). 
Rainfall characterization is important to define the range of magnitude and patterns that the set of monitored events provided. The information obtained from the runoff data and its relationship with rainfall is essential to define the proportion of the rainfall that is converted into runoff, which has a high potential for degradation. The information related to lag times reflects the effects of the roughness generated by the different managements applied in runoff propagation time. The effects are due to terracing in the catchments and land surface roughness imposed by the amount of phytomass and/or chiseling in the macroplots. The results of each variable were analyzed using the paired t-test to compare the means of each monitoring unit. The mean of the variables of each unit is compared by considering that each event can be paired with the observations in the other unit. Statistical significance was expressed as a p-value, followed by a Student's t-distribution under the null hypothesis that there is no difference between treatments (Casella \& Berger, 2010).

\section{b) Total apparent infiltration}

The concept of apparent infiltration rate $\left(\mathrm{I}_{\mathrm{ap}}, \mathrm{mm} \mathrm{h}^{-1}\right)$ (Rose, 2004) was used to demonstrate the infiltration pattern as a function of rainfall intensity $\left(\mathrm{mm} \mathrm{h}^{-1}\right)$. Analysis of all instantaneous values led to Eq. 1, where $I_{a p}$ is calculated by the difference between the instantaneous values of rainfall intensity $\left(\mathrm{R}, \mathrm{mm} \mathrm{h}^{-1}\right)$ and runoff $\left(\mathrm{Q}, \mathrm{mm} \mathrm{h}^{-1}\right)$.

$$
I_{a p}=R_{i}-Q_{i}
$$

The analysis was performed with the paired values of $R$ and $I_{a p}$ for all events to characterize each monitoring unit. The model obtained (Iap $=f\left(\mathrm{R}, \mathrm{I}_{\mathrm{m}}\right)$ shows the infiltration rate behavior as a function of the rainfall intensity and an estimate of the maximum infiltration rate of the unit $\left(\mathrm{I}_{\mathrm{m}}\right)$. The model obtained in each unit and $\mathrm{I}_{\mathrm{m}}$ values were compared to determine the influence of the controlling factors on infiltration in each unit.

\section{c) Curve number method (CN-SCS)}

The CN model (NRCS, 2004) is a widely used method in hydrological models to estimate runoff generated in a rainfall event as a function of the rainfall (P), initial abstractions $\left(I_{a}\right)$, and the estimate of the maximum water storage capacity of the soil $(S)$. The value of $S$ is estimated according to an empirical parameter called $\mathrm{CN}$. This dimensionless parameter varies between 0 and 100 and represents the soil characteristics regarding permeability, use, and soil management. The $\mathrm{CN}$ parameter was empirically derived from a network of experimental catchments in the USA to design conservation practices (Hawkins et al., 2009). In this study, S and $\mathrm{CN}$ values were estimated for each event and the different monitoring units, considering the monitored values of rainfall ( $\mathrm{mm})$ and runoff ( $\mathrm{mm})$ using Eqs. 2 and 3: 
$S=5\left[P+2 Q-\sqrt{\left(4 Q^{2}+5 P Q\right)}\right]$

299

$$
C N=\frac{25400}{(S+254)}
$$

300

301

302

303

304

305

306

307

308

309

310

311

312

313

314

315

316

317

318

319

320

321

322

323

324

325

326

327

328

329

330

331

332

333

334

335

336 337

\section{Results}

The El Niño climate phenomenon occurred from 2014 to 2015 and generated aboveaverage rainfall, increasing high-magnitude rainfall events. In 2016, the La Niña climate phenomenon reduced the number of monitored events (NOAA, 2018). This time series favored the analysis of the hydrological behavior in the monitoring units in contrasting conditions (e.g., high soil moisture and low soil coverage). Moreover, runoff occurred in events of all magnitudes, from small rainfall events $(14 \mathrm{~mm})$ to the largest one $(160 \mathrm{~mm})$. The boxplot of Figure 4 shows the median (middle line), first and quartile (box), maximum and minimum values (whiskers), and extreme values (points) of the $\mathrm{R}$ monitored at three different durations $(10,30$, and $60 \mathrm{~min})$. The 30-min rainfall intensity $\left(\mathrm{R}_{30}\right)$ reached the average magnitude of 25 $\mathrm{mm} \mathrm{h}^{-1}$ and several events with values $>50 \mathrm{~mm} \mathrm{~h}^{-1}$.

Figure 4. Rainfall intensity for 10, 30, and 60-min intervals.

The main characteristics of the rainfall to represent its magnitude are shown in Table 3. Six events (9\%) had a RP of rainfall between 1 and 10 years, five events ( $8 \%$ ) between 11 and 70 years, and one event (1.6\%) exceeded the 100 -year RP.

Table 3. Major rainfall events classified by decreasing return periods.

\subsection{Zero-order catchments}

\section{a) Hydrological characteristics}

The runoff in the study period, considering the 63 monitored events, is described in Figure 5. The terraces (TC) significantly reduced runoff ( $p$-value $=0.038$ ). The terraces overflowed in some events, especially in 2015, although there was a significant reduction in runoff volume during these events. On average, the terraces reduced runoff by $56 \%$, despite the reduction tending to be greater in smaller events. It should be noted that 2015 was the year with the highest number of high magnitude events (1413 $\mathrm{mm}$ of total monitored rainfall), where the total runoff was $19 \%$ in the NTC and $10 \%$ in the TC. Furthermore, there was $781 \mathrm{~mm}$ of rainfall monitored in 2017, which provided $13 \%$ of runoff in the NTC and $6 \%$ in the TC.

Figure 5. Rainfall and total runoff volume in the NTC and TC during rainfall events. 
The terraces (TC) significantly reduced runoff coefficient ( $p$-value $=0.001$ ), and their efficiency is presented through the runoff coefficient (RC) considering similar periods in terms of rainfall regime (dry and wet years) (Figure 6). Approximately $45 \%$ of all monitored events in the NTC showed C values above 10\%, with RC exceeding 50\% in some events (Figure 6).

Figure 6. Values of runoff coefficient (RC) in the NTC and TC.

$\mathrm{Q}_{\text {peak }}$ analysis also showed a significant difference $(\mathrm{p}$-value $=0.024)$ between the NTC and TC (Figure 7). The terraces contributed to $\mathrm{Q}_{\text {peak }}$ reduction by lowering the volume in the events in which there was overflow. This can be seen in three major overflowing events (RP: 43,19 , and 2 years) in 2015. The $\mathrm{Q}_{\text {peak }}$ values significantly decreased in the TC. In one of the largest monitored events in $2014(07 / 23 / 2014)$, the values reported were $117 \mathrm{~L} \mathrm{~s}^{-1}$ for the NTC and $34 \mathrm{~L} \mathrm{~s}^{-1}$ for the TC when the terraces did not overflow.

Figure 7. Differences in peak flow $\left(\mathrm{Q}_{\text {peak }}\right)$ between the NTC and TC.

$Q_{\text {peak }}$ is affected by surface roughness and is mainly controlled by relief characteristics, including the slope, slope length, and slope shape. In this case, the terraces decreased the effective slope length by reducing $\mathrm{Q}_{\text {peak }}$ by runoff detention and delaying runoff propagation when there was overflow. Some of the delay variables (lag time) demonstrate the effects of terracing in propagating runoff more clearly and explicitly. Among them, we highlight the TLP (time between the beginning of rainfall and peak runoff), TLPC (time between the centroid of the hyetograph and the peak runoff), TLC (Time between the hyetogram centroid and the hydrogram centroid) indices that showed the differences between the catchments, and TLR (time between the beginning of the rainfall and the beginning of the runoff). The higher values of these lag times indicate the positive effect of these management measures on runoff behavior. The differences observed in four of the main lag time variables analyzed are shown in Figure 8.

Figure 8. The behavior of three Lag Time variables (TLC, TLP, TLPC, and TLR) for the set of events monitored at NTC and TC.

As observed for $\mathrm{Q}_{\text {peack}}$, the terraces reduced the runoff volume and increased its propagation time on the surface. The average of all events indicates that the terraces increased the TLR by $27 \%$ ( $\mathrm{p}$-value $=0.2323$ ). By separating the events into two groups (low and high phytomass), the combined effects of terracing with the amount of phytomass was observed. Under the high coverage condition ( $\sim 11 \mathrm{tha}^{-1} \mathrm{y}^{-1}$ of phytomass), the values were 65 and $75 \mathrm{~min}$ in the NTC and TC, respectively, while the values were 70 and $102 \mathrm{~min}$ at the NTC and TC, respectively, under low coverage ( $\sim 6 \mathrm{tha}^{-1} \mathrm{y}^{-1}$ of phytomass). Analysis of the TLC values showed that the averages were similar and that the extreme values were affected by the terraces, thus further underlining their importance since their efficiency is mainly expected in high magnitude events. The average of all events indicates that the terraces increased the TLP by 
$38015 \%(\mathrm{p}$-value $=0.0391)$. The mean TLPC values were similar between NTC and TC, with no 381 significant differences between them.

382

b) Apparent infiltration

The apparent total infiltration $\left(I_{a p}\right)$ was estimated using data pairs $\left(I_{a p}\right.$ and $\left.R\right)$ and considering 30-min intervals (Figure 9). The distribution generates different regions in the graphs: a) $\mathrm{R}_{30}<25 \mathrm{~mm} \mathrm{~h}^{-1}$, b) $25<\mathrm{R}_{30}<65 \mathrm{~mm} \mathrm{~h}^{-1}$, and $\mathrm{R}_{30}>65 \mathrm{~mm} \mathrm{~h}^{-1}$. In the first section, $\mathrm{I}_{\text {ap }} \approx \mathrm{R}$ and practically all the rainfall infiltrates. In the intermediate section, there is high data dispersion due to the influence of soil moisture in the infiltration process (i.e., infiltration may be higher or lower depending on the initial soil moisture in similar R values). In the final section, there is a tendency to form an asymptote that expresses the maximum possible infiltration.

Figure 9. Total apparent infiltration model for 30-min rainfall intensities at the NTC and TC.

Equations 4 and 5 describe the apparent total infiltration model of each catchment. The values of 95 and $154 \mathrm{~mm} \cdot \mathrm{h}^{-1}$, in the NTC and TC, respectively, mathematically express the asymptote of the curve and physically express the maximum infiltration limit when the 399

$$
\begin{gathered}
I_{a p}=95 *\left[1-\exp \left(\frac{-R}{95}\right)\right] \\
I_{a p}=154 *\left[1-\exp \left(\frac{-R}{154}\right)\right]
\end{gathered}
$$

400

401

402

403

404

405

406

407

408 409

\section{c) Determination of the $\mathrm{CN}$ parameter}

The $\mathrm{CN}$ values determined in both catchments for all events are shown in Figure 10. The average CN values for the NTC and TC were 69 and 59, respectively, clearly showing the effects of terracing. The figure also shows the analysis of $\mathrm{CN}$ behavior as a function of rainfall. Moreover, there is a clear difference in the distribution of points between both catchments.

Figure $10 . \mathrm{CN}$ values as a function of the rainfall that occurred during the monitoring period.

The points are close to the curve that defines the $\mathrm{CN}_{0}$ value at the $\mathrm{TC}$, while the points have greater dispersion and are farther from the $\mathrm{CN}_{0}$ curve at the NTC, showing the inefficiency of the system in controlling runoff. The $\mathrm{CN}_{0}$ curve represents the minimum runoff value for a given rainfall event (Soil Conservation Service Engineering Division, 1972).

\subsection{Macroplots}




\section{7}

418

419

420

421

422

423

424

425

426

427

428

429

430

431

432

433

434

435

436

437

438

439

440

441

442

443

444

445

446

447

448

449

450

The macroplots are cultivated under NT with different soil (chiseling versus no chiseling) and crop management systems (low versus high phytomass addition) without terracing. The results of this set of monitoring units reflect the efforts to control runoff without the terraces and by only covering the soil via crops in succession and rotation and chiseling. The monitoring includes 27 events with different climatic and land cover conditions. The total rainfall monitored during events that generated runoff was $1648 \mathrm{~mm}$. The highest intensity rainfall for 30 -min intervals occurred on $05 / 26 / 2017$ with $115 \mathrm{~mm} \mathrm{~h}^{-1}$ and $03 / 15 / 2018$ with 84 $\mathrm{mm} \mathrm{h}^{-1}$.

\section{a) Characteristic variables}

The different management practices applied in the macroplots led to small differences in the total amount of runoff monitored during events. Macroplots M1 and M2 have low phytomass addition (LF), M1 with chiseling (CLF) and M2 without chiseling (NC + LF). In $\mathrm{M} 1$, there were $14.9 \%$ of water losses due to runoff, and $21.1 \%$ in M2 (p-value $=0.35$ ), considering the average for the whole period. For this condition of low phytomass supply, chiseling reduced runoff by approximately $6 \%$. Macroplots M3 and M4 have high phytomass addition (HF) due to improved plant management through crop rotation, M3 scarified with chiseling (CHF), and M4 without chiseling (NCHF). There was 13.6\% of water loss through runoff in M3 and $15.8 \%$ in M4 (p-value $=0.63$ ), considering the average for the whole period. Chiseling was less efficient in reducing runoff (only $2 \%$ ). Moreover, comparing the effects of phytomass input with chiseling (M1 versus M3) showed an insignificant difference $(0.7 \%)$ (pvalue $=0.97$ ), while comparing the effects of phytomass without chiseling (M2 versus M4) revealed a difference of approximately $4 \%(\mathrm{p}$-value $=0.64)$. The results of the runoff coefficient over the years of monitoring are presented in Figure 11.

Figure 11. Variation of the runoff coefficient in the macroplots.

The efficiency of soil (chiseling and no-till) and crop management (with and without crop rotation) in controlling runoff during rainfall-runoff events was low. The runoff coefficient (RC) was above $10 \%$ in $41 \%$ of the events, with CLF being the worst condition, where in addition to not having crop rotation, the soil was chiseled up to $30 \mathrm{~cm}$ in depth, thus emphasizes that chiseling without the additional biological effects does not effectively mitigate erosion processes. More than half of the rainfall volume monitored on 12/24/2015 was lost by runoff under the low biomass condition, being 55 and $62 \%$ in M1 and M2, respectively. The highest amount of phytomass generated runoff coefficients of 43 and 53\% in M3 and M4, respectively, for the 12/24/2015 event. The small RC difference between phytomass additions demonstrates that runoff from the crops is significant in high magnitude events and that other runoff control measures are necessary. We emphasize events of great magnitude as these are responsible for the highest levels of degradation and water losses. The behavior of the $\mathrm{Q}_{\text {peak }}$ monitored in each event is shown in Figure 12. The magnitude of $\mathrm{Q}_{\text {peak }}$ expresses the potential for soil degradation by runoff. 
460 Figure 12. The difference of $\mathrm{Q}_{\text {peak }}$ on the events monitored in the four macroplots.

461

462

463

464

465

466

467

468

469

470

471

472

473

474

475

476

477

478

479

480

481

482

483

484

485

486

487

488

489

490

491

492

493

494

495

496

497

498

499

500

501

Despite the importance of phytomass production to improve soil structure, which occurs in the medium/long term, its effects on runoff control have been reduced. This $\mathrm{Q}_{\text {peak }}$ behavior can be visualized in three different representative events: 08/13/2017, 12/24/2015, and 05/26/2017 (Figure 13). The 08/13/2017 event, for example, had an accumulated volume of 80 $\mathrm{mm}$ rainfall, with a long duration and low intensity. In this condition, the macroplots showed a dense vegetation cover provided by the wheat (M1 and M2) and black oats (M3 and M4) and in the physiological stage of full flowering. Despite the dense ground cover, the systems responded directly to the increased rainfall intensity, with the greatest response in M2 (NCLF), even under low rainfall conditions. Despite good soil coverage by vegetation and low rainfall intensity, the soil and plant management systems could not control runoff.

Figure 13. Hyetograph and hydrograph characteristics in the macroplots.

Most lag time parameters in the four macroplots had no significant differences, demonstrating the influence of surface characteristics and their potential to cause friction (Figure 14. ). The mean TLR values of the macroplots with low phytomass was $105 \mathrm{~min}$ in M1 and $121 \mathrm{~min}$ in M2. In M3 and M4 (greater phytomass amount), the values were 125 and 132 min, respectively.

The concentration time (Tc) showed the most significant variation among the systems (Figure 14), despite the absence of statistical difference. The mean Tc values of the macroplots with low phytomass (LF) was approximately $122 \mathrm{~min}$ in M1 and $153 \mathrm{~min}$ in M2 (p-value = 0.47). In M3 and M4, the Tc values were approximately 105 and $96 \mathrm{~min}$, respectively (p-value $=0.81$ ). When considering the upper quartile values in M3 and M4 compared with M2, there is a reduction of approximately $50 \mathrm{~min}$. However, the reduction is approximately $100 \mathrm{~min}$ for the maximum values. The other variables tested (TLPC, TLC, and TLR) were similar in the four systems.

Figure 14. Behavior of time lag variables for the set of events monitored in the macroplots.

b) Apparent infiltration

The $P$ and Q data for each event were used to calculate the apparent infiltration $\left(I_{a p}\right)$ and allowed the construction of the infiltration models for the four macroplots (Figure 15). As in the catchments, the different infiltration behavior for the three ranges of rain intensity is evident. For intensity $\left(\mathrm{R}_{30}\right)$ below $40 \mathrm{~mm} \mathrm{~h}^{-1}$, practically the entire rainfall precipitated layer infiltrates; b) for rain intensities between 40 and $100 \mathrm{~mm} \mathrm{~h}^{-1}$, there is a strong influence of the antecedent humidity in the definition of infiltration or runoff formation; and c) for an intensity greater than $100 \mathrm{~mm} \mathrm{~h}^{-1}$, there is a tendency to form an asymptotic behavior that would indicate the maximum infiltration capacity in each macroplot. 
502

503

504

505

506

507

508

509

510

511

512

513

514

515

516

517

518

519

520 521

522

523

524

525 526

527 528

529

530

531

532

533

534

535

536

537

538

539

540

541

542

543

Figure 15. Relationship between the total apparent infiltration and maximum rainfall intensity of $30 \mathrm{~min}$ for the macroplots.

The high phytomass addition system with chiseling provided better infiltration conditions. The influence of phytomass was more effective that chiseling in both soil cover conditions which demonstrates that the biological effects are more efficient than the mechanical effects on soil structure recovery. There was a higher infiltration rate with high coverage condition (M3: CHF and M4: NCHF) comparing with low coverage (CLF: M1 and NCLF: M2). . Chiseling mitigated runoff losses for both soil cover condition.

c) Determination of the $\mathrm{CN}$ parameter

The $\mathrm{CN}$ values were sensitive to the influence of chiseling and phytomass input. The median CN values for M1, M2, M3, and M4 were 61, 66, 57, and 59, respectively (Figure 16). There is a greater discrepancy in the behavior of the M2 values compared to the other systems, showing that the simple adoption of no-till without chiseling and phytomass input increases runoff.

Figure 16. The $\mathrm{CN}$ values estimated for the set of events monitored in the macroplots.

The analysis of the dispersion of $\mathrm{CN}$ data as a function of rainfall is shown in Figure 17. Unlike what was found in the TC, all macroplots have $\mathrm{CN}$ values with high dispersion distant from the $\mathrm{CN}_{0}$ curve. Despite the difference in the median values in Figure 15, there is no clear breakdown of the effects of phytomass amount and chiseling on the set of points.

Figure 17. Dispersion of $\mathrm{CN}$ values as a function of rainfall in the macroplots.

\section{Discussion}

\subsection{Runoff control}

Alternative farming practices, such as those providing high phytomass input through crop rotation and/or chiseling were not enough to control runoff $(\mathrm{C}>10 \%)$. The monitoring results showed no reduction in $\mathrm{Q}, \mathrm{Q}_{\text {peak }}$, and $\mathrm{C}$ values compared to the high phytomass amount in M3 and M4 in relation to M1 and M2 or the presence of chiseling in M1 and M3 regarding M2 and M4. Although the effects of both practices were not very significant, it is clear that the effects of soil cover density by vegetation were more efficient than chiseling in controlling runoff. Chiseling is commonly used to control runoff, although its effects are short-lived (Drescher, Eltz, Denardin, \& Faganello, 2011; Drescher et al., 2016). Phytomass supply through crop rotation allows permanent coverage of soil surface with vegetation and contributes to improving the soil structure, increasing soil water infiltration and storage (Groff, 2015). The positive effects of higher phytomass input (M3 and M4) were observed in all magnitudes of events, but this was not enough to control the runoff completely. The runoff control during high 
544 magnitude rainfall events are extremely important in soil degradation processes even with a low 545 frequency of occurrence, as demonstrated by Falloon and Betts (2010) and Rodriguez-Lloveras 546 et al. (2015).

The results obtained in the macroplots show that the partial adoption of conservation 548 practices is not enough to control the degradation processes associated with runoff. This 549 observation was already reported by Didoné et al. (2014) and Tiecher et al. (2017) under similar 550 soil use and management conditions in southern Brazil and at the catchment scale. The runoff 551 formation during significant magnitude events also depends on complementary practices, such 552 as terracing. Land management is the main runoff driving factor during extreme events. Unlike 553 the effects of adding phytomass and chiseling, the significant reduction in volume, $\mathrm{Q}_{\text {peak }}$, and 554 runoff coefficient in the TC compared to the NTC strengthens the need to adopt terracing 555 (Arnáez, Lana-Renault, Lasanta, Ruiz-Flaño, \& Castroviejo, 2015; Merten et al., 2015; Pfister, 556 Bayer, Koehler, \& Hellweg, 2011).

The estimate of apparent infiltration $\left(\mathrm{I}_{\mathrm{ap}}\right)$ in the macroplots and paired catchments was 558 also sensitive to the adopted management systems. According to Barros, Minella, Tassi, 559 Dalbianco, and Ottonelli (2014), unlike traditional methods, $\mathrm{I}_{\text {ap }}$ incorporates other processes 560 that act in the landscape to express the real infiltration and its relationship with runoff formation. 561 The infiltration models showed that its magnitude to higher values of rainfall is different for the 562 three management systems. The highest infiltration rates were found in the terraced condition, 563 followed by the largest amount of phytomass and, finally, the effects of chiseling.

In the analysis of $I_{a p}$ in the macroplots, the phytomass input efficiency was greater than 566 physical-hydraulic properties, which control water infiltration and indicate the structural state 567 of the soil, may have a shorter duration than an agricultural harvest (Drescher et al., 2011, 568 2016). Meanwhile, crop rotation carried out for long periods increases phytomass supply, 569 maintains the soil surface permanently covered, presents a different root system, and improves 570 the physical, chemical, and biological quality of the soil (Groff, 2015).

571 The analysis of the pattern of variation of the CN values between the NTC and TC 572 demonstrated a significant difference imposed by the terraces. The $\mathrm{CN}$ values in the TC are 573 close to those defined by the $\mathrm{CN}_{0}$ curve (Soil Conservation Service Engineering Division, 574 1972), while the values in the NTC were higher and had a completely different behavior 575 depending on the magnitude of rainfall. The determination of the $\mathrm{CN}=\mathrm{f}(\mathrm{P})$ model is useful to 576 develop conservation projects, as it allows the dimensioning of drainage control practices 577 (Ajmal, Waseem, Kim, \& Kim, 2020; Lian et al., 2020). Determining the CN values for local 578 conditions of climate, use, and management are essential to efficiently determine the 579 appropriate practices (Do Valle Junior et al., 2019). The CN values derived in this study, for 580 the conditions with and without terracing under no-till, may improve soil and water 581 conservation planning under conditions similar to the experiment in southern Brazil, as 582 corroborated by Barros et al. (2014). The lower sensitivity of the characteristic variables and 583 the $\mathrm{CN}$ in the macroplots compared to the catchments implies the roughness imposed by the 584 amount of phytomass and chiseling is not enough to control runoff. Castro, Cogo, and Volk 585 (2006) emphasized that NT reduces soil roughness, which may increase water losses. This was 586 observed in the present study when comparing NT with chiseling. In addition, when sowing is 
587 carried out in the direction of the slope, preferential channels are formed that increase runoff 588 speed. The monitored values of $\mathrm{Q}_{\text {peak }}$ in both the NTC and macroplots show the erosive potential 589 of runoff in NT when the water management system (terracing) was not carried out. It is 590 important to emphasize the importance of the relief as a runoff-controlling factor. Even under 591 NT with intense soil cover and chiseling, there are places sensitive to runoff formation that may 592 trigger erosion processes. Hence, topographic indices may help identify the most sensitive 593 regions on the slopes, either due to the greater erosive capacity of the runoff or the presence of 594 wet areas (Minella \& Merten, 2012).

595 Roughness is a fundamental factor in increasing friction to runoff and reducing its speed 596 (Hansen, Schjønning, \& Sibbesen, 1999; Takken, Jetten, Govers, Nachtergaele, \& Steegen, 597 2001), increasing infiltration. In the analysis of the different lag times under contrasted farming 598 practices, the greater coverage increased the roughness, although it was not enough to 599 effectively control runoff speed during the events of greater magnitude. In contrast, the positive 600 effects of terracing in the TC compared to the NTC in the lag times is evident. Reducing runoff 601 speed is essential to increase energy dissipation that controls erosion processes (Giménez \& 602 Govers, 2008; Gómez \& Nearing, 2005). Nonetheless, this is a challenge for the current 603 agricultural systems, which need to adopt management systems that can contain the spread of 604 runoff and reduce their kinetic energy. Despite the importance and need for soil cover for 605 numerous soil functionalities, its efficiency is relatively small in controlling runoff during high 606 magnitude events ( $\mathrm{RP}>1$ year) compared to terracing, which has proved to be an efficient 607 alternative in mitigating conservation and environmental problems related to soil degradation. 608 The runoff control in the NT is one of the main challenges of this agricultural production 609 system. It is important to emphasize that runoff dynamics and controlling erosion processes 610 also regulate the processes of water contamination by the dissolved elements associated with 611 the transported sediment load containing fertilizers and pesticides (Exterkoetter et al., 2019). 612 Avoiding excess runoff is a way to reduce the risks of contaminating natural resources (Zuazo 613 et al., 2011) and ensuring that water is stored in the plant's rooting zone and, thereby, increasing 614 its efficiency for agricultural production (Lal, 2008). The impacts resulting from runoff in areas 615 under NT and that do not adopt conservationist principles are recurrent. Thus, this soil 616 management system increases the fragility of slopes under agricultural production, 617 consequently accelerating erosion processes (Didoné et al., 2014; Kassam, Derpsch, \& 618 Friedrich, 2014; Merten et al., 2015).

\section{Conclusions}

The information obtained allows us to conclude that the high phytomass input by crop 624 complast terracing significantly reduced runoff variables, demonstrating its importance as a 625 evaluation of catchments and macroplots allowed the quantification of the response of all units 626 in the same rainfall event with contrasting water, soil, and plant management conditions. Even 627 in a short period of monitoring, such as the one carried out in this study, it was possible to 
628 generate a set of relevant information. The runoff monitoring allowed the estimation of 629 parameters necessary to quantify the apparent infiltration $\left(\mathrm{I}_{\mathrm{ap}}\right)$ and runoff $\left(\mathrm{CN}, \mathrm{C}\right.$, and $\left.\mathrm{Q}_{\text {peak }}\right)$,

630 which are fundamental to design conservation practices in NT at the catchment scale.

631

632

633

634

635

636

637

638

639

640

641

642

643

644

645

646

647

648

649

650

651

652

653

654

655

656

657

658

659

660

661

662

663

664

665

666

667

668

669

670

671

The high monitoring frequency associated with the monitoring of paired units optimized the results for a short monitoring period (5 years), which was essential to obtain additional information to compare different management effects. Furthermore, monitoring showed the importance of improving water management by reducing runoff and controlling erosion processes. This study also demonstrated the importance of monitoring projects for locally defining parameters and information for mathematical modeling. The quantification of runoff in extreme rainfall events ( $\mathrm{RP}>20$ years) was essential to assess the weak ability of no-till to resist the effects of runoff and the need to develop a more sustainable production system. Approaches based on mathematical modeling supported by catchment monitoring databases may help evaluate and recommend the best management practices.

\section{Acknowledgments}

The authors acknowledge the financial support granted by the Maiságua Project of the FEPAGRO (State Foundation of Agricultural Research), the FINEP (Funding for Studies and Projects), and CNPq (National Council of Scientific and Technologic Development).

\section{References}

Ajmal M, Waseem M, Kim D, Kim TW. 2020. A pragmatic slope-adjusted curve number model to reduce uncertainty in predicting flood runoff from steep watersheds. Water (Switzerland) 12 (5) DOI: 10.3390/w12051469

Alaoui A, Rogger M, Peth S, Blöschl G. 2018. Does soil compaction increase floods? A review. Journal of Hydrology 557: 631-642 DOI: 10.1016/j.jhydrol.2017.12.052

Almagro A, Oliveira PTS, Nearing MA, Hagemann S. 2017. Projected climate change impacts in rainfall erosivity over Brazil. Scientific Reports 7 (1): 1-12 DOI: 10.1038/s41598-01708298-y

Alvares CA, Stape JL, Sentelhas PC, De Moraes Gonçalves JL, Sparovek G. 2013. Köppen's climate classification map for Brazil. Meteorologische Zeitschrift 22 (6): 711-728 DOI: 10.1127/0941-2948/2013/0507

Arnáez J, Lana-Renault N, Lasanta T, Ruiz-Flaño P, Castroviejo J. 2015. Effects of farming terraces on hydrological and geomorphological processes. A review. Catena 128: 122134 DOI: 10.1016/j.catena.2015.01.021

Barros CAP de, Minella JPG, Tassi R, Dalbianco L, Ottonelli AS. 2014. Estimativa da infiltração de água no solo na escala de bacia hidrográfica. Revista Brasileira de Ciência do Solo 38 (2): 557-564 DOI: 10.1590/S0100-06832014000200020

Basche A. 2017. Turning Soils into Sponges: How Farmers Can Fight Floods and Droughts: 18 pp.

Casella G, Berger RL. 2010. Statistical inference. Thomson Learning. 660p.

Castro LG, Cogo NP, Volk LB da S. 2006. Alterações na rugosidade superficial do solo pelo preparo e pela chuva e sua relação com a erosão hídrica. Revista Brasileira de Ciência do 
672

673

674

675

676

677

678

679

680

681

682

683

684

685

686

687

688

689

690

691

692

693

694

695

696

697

698

699

700

701

702

703

704

705

706

707

708

709

710

711

712

Solo 30 (2): 339-352 DOI: 10.1590/S0100-06832006000200014

Caviglione JH, Fidalski J, Araújo AG de, Barbosa GM de C, Llanillo RF, Souto AR. 2010. Espaçamento entre terraços em plantio direto. Boletim Técnico IAPAR 1 (1): 59 P. DOI: 10.1017/CBO9781107415324.004

Delgado J a., Groffman PM, Nearing M a., Goddard T, Reicosky D, Lal R, Kitchen NR, Rice CW, Towery D, Salon P. 2011. Conservation practices to mitigate and adapt to climate change. Journal of Soil and Water Conservation 66 (4): 118A-129A DOI: 10.2489/jswc.66.4.118A

Derpsch R, Friedrich T, Kassam A, Hongwen L. 2010. Current status of adoption of no-till farming in the world and some of its main benefits. International Journal of Agricultural and Biological Engineering 3 (1): 1-25 DOI: 10.3965/j.issn.1934-6344.2010.01.001-025

Deuschle D, Minella JPG, Hörbe T de AN, Londero AL, Schneider FJA. 2019. Erosion and hydrological response in no-tillage subjected to crop rotation intensification in southern Brazil. Geoderma 340 (July 2018): 157-163 DOI: 10.1016/j.geoderma.2019.01.010

Didoné EJ, Minella JPG, Reichert JM, Merten GH, Dalbianco L, de Barros CAP, Ramon R. 2014. Impact of no-tillage agricultural systems on sediment yield in two large catchments in Southern Brazil. Journal of Soils and Sediments 14 (7): 1287-1297 DOI: 10.1007/s11368-013-0844-6

\section{Dingman, SL. 2015. Physical hydrology. 2 ed. GARG}

Drescher MS, Eltz FLF, Denardin JE, Faganello A. 2011. Persistência do efeito de intervenções mecânicas para a descompactação de solos sob plantio direto. Revista Brasileira de Ciência do Solo 35 (5): 1713-1722 DOI: 10.1590/S0100-06832011000500026

Drescher MS, Reinert DJ, Denardin JE, Gubiani PI, Faganello A, Drescher GL. 2016. Duração das alterações em propriedades físico-hídricas de Latossolo argiloso decorrentes da escarificação mecânica. Pesquisa Agropecuária Brasileira 51 (2): 159-168 DOI: 10.1590/S0100-204X2016000200008

Exterkoetter R, Rozane DE, da Silva WC, Toci AT, Cordeiro GA, Benassi SF, Boroski M. 2019. Potential of terracing to reduce glyphosate and AMPA surface runoff on Latosol. Journal of Soils and Sediments: 1-11 DOI: 10.1007/s11368-018-2210-1

Falloon P, Betts R. 2010. Climate impacts on European agriculture and water management in the context of adaptation and mitigation-The importance of an integrated approach. Science of the Total Environment 408 (23): 5667-5687 DOI: 10.1016/j.scitotenv.2009.05.002

FAO. 2015. FAO Statistical Pocketbook 2015. DOI: 978-92-5-108802-9

Friedrich T, Derpsch R, Kassam A. 2012. Overview of the Global Spread of Conservation Agriculture Overview of the Global Spread of Conservation Agriculture. (6): 0-7

Le Gall M, Evrard O, Dapoigny A, Tiecher T, Zafar M, Minella JPG, Laceby JP, Ayrault S. 2017. Tracing Sediment Sources in a Subtropical Agricultural Catchment of Southern Brazil Cultivated With Conventional and Conservation Farming Practices. Land Degradation and Development 28 (4) DOI: 10.1002/1dr.2662 

rills in eroding rills. (March 2001) DOI: 10.1029/2000WR900252

Gómez JA, Nearing MA. 2005. Runoff and sediment losses from rough and smooth soil surfaces in a laboratory experiment. Catena 59 (3): 253-266 DOI: 10.1016/j.catena.2004.09.008

Groff S. 2015. The past, present, and future of the cover crop industry. Journal of Soil and Water Conservation 70 (6): 130A-133A DOI: 10.2489/jswc.70.6.130A

Hansen B, Schjønning P, Sibbesen E. 1999. Roughness indices for estimation of depression storage capacity of tilled soil surfaces. Soil and Tillage Research 52 (1-2): 103-111 DOI: 10.1016/S0167-1987(99)00061-6

Hawkins RH, Ward TJ, Woodward DE, Van Mullem JA. 2009. Curve number hydrology: State of the practice (RH Hawkins, TJ Ward, DE Woodward, and JA Van Mullem, eds). American Society of Civil Engineers: Reston, VA. DOI: 10.1061/9780784410042

Huang MB, Gallichand J, Zhang PC. 2003. Runoff and sediment responses to conservation practices: Loess plateau of china. Journal of the American Water Resources Association 39 (5): 1197-1207 DOI: Doi 10.1111/J.1752-1688.2003.Tb03702.X

Hussein MH, Amien IM, Kariem TH. 2016. Designing terraces for the rainfed farming region in Iraq using the RUSLE and hydraulic principles. International Soil and Water Conservation Research 4 (1): 39-44 DOI: 10.1016/j.iswcr.2015.12.002

Ipcc. 2013. Summary for Policymakers. Climate Change 2013: The Physical Science Basis. Contribution of Working Group I to the Fifth Assessment Report of the Intergovernmental Panel on Climate Change: 33 DOI: 10.1017/CBO9781107415324

Jagercikova M, Cornu S, Le Bas C, Evrard O. 2014. Vertical distributions of 137Cs in soils: a meta-analysis. Journal of Soils and Sediments 15 (1): 81-95 DOI: 10.1007/s11368-0140982-5

Kassam A, Derpsch R, Friedrich T. 2014. Global achievements in soil and water conservation: The case of Conservation Agriculture. International Soil and Water Conservation Research 2 (1): 5-13 DOI: 10.1016/S2095-6339(15)30009-5

Lal R. 2008. Managing soil water to improve rainfed agriculture in India. Journal of Sustainable Agriculture 32 (1): 51-75 DOI: 10.1080/10440040802121395

Lian H, Yen H, Huang JC, Feng Q, Qin L, Bashir MA, Wu S, Zhu AX, Luo J, Di H, et al. 2020. CN-China: Revised runoff curve number by using rainfall-runoff events data in China. Water Research 177: 115767 DOI: 10.1016/j.watres.2020.115767

Londero AL, Minella JPG, Deuschle D, Schneider FJA, Boeni M, Merten GH. 2017. Impact of broad-based terraces on water and sediment losses in no-till (paired zero-order) catchments in southern Brazil. Journal of Soils and Sediments (2009): 1-17 DOI: 10.1007/s11368017-1894-y

Merten GH, Araújo AG, Biscaia RCM, Barbosa GMC, Conte O. 2015. No-till surface runoff and soil losses in southern Brazil. Soil and Tillage Research 152: 85-93 DOI: 10.1016/j.still.2015.03.014

Minella JPG, Merten GH. 2012. Índices topográficos aplicados à modelagem agrícola e ambiental. Ciência Rural 42 (9): 1575-1582 DOI: 10.1590/S0103-84782012000900010

Mishra SK, Tyagi J V., Singh VP, Singh R. 2006. SCS-CN-based modeling of sediment yield. Journal of Hydrology 324 (1-4): 301-322 DOI: 10.1016/j.jhydrol.2005.10.006

Nadal-Romero E, Peña-Angulo D, Regüés D. 2018. Rainfall, run-off, and sediment transport 
dynamics in a humid mountain badland area: Long-term results from a small catchment. Hydrological Processes 32 (11): 1588-1606 DOI: 10.1002/hyp.11495

NOAA. 2018. Climate Prediction Center. National Weather Service

NRCS NRCS. 2004. Hydrologic Soil-Cover Complexes. Part 630 H (July 2004)

Oliveira PTS, Nearing MA, Hawkins RH, Stone JJ, Rodrigues DBB, E. Panachuki A, Wendland E. 2016. Curve number estimation from Brazilian Cerrado rainfall and runoff data. Journal of Soil and Water Conservation 71 (5): 420-429 DOI: 10.2489/jswc.71.5.420

Olley J, Brooks A, Spencer J, Pietsch T, Borombovits D. 2013. Subsoil erosion dominates the supply of fine sediment to rivers draining into Princess Charlotte Bay, Australia. Journal of Environmental Radioactivity 124: 121-129 DOI: 10.1016/j.jenvrad.2013.04.010

Pfister S, Bayer P, Koehler A, Hellweg S. 2011. Projected water consumption in future global agriculture: Scenarios and related impacts. Science of the Total Environment 409 (20): 4206-4216 DOI: 10.1016/j.scitotenv.2011.07.019

Polyakov VO, Nearing MA, Nichols MH, Scott RL, Stone JJ, McClaran MP. 2010. Long-term runoff and sediment yields from small semiarid watersheds in southern Arizona. Water Resources Research 46 (9) DOI: 10.1029/2009WR009001

Pruski FF, Griebeler NP, Silva DD da. 2001. Comparação entre dois métodos para a determinação do volume de escoamento superficial. Revista Brasileira de Ciência do Solo 25 (2): 403-410 DOI: 10.1590/S0100-06832001000200016

Reicosky DC. 2015. Conservation tillage is not conservation agriculture. Journal of Soil and Water Conservation 70 (5): 103A-108A DOI: 10.2489/jswc.70.5.103A

Ribeiro KH, Favaretto N, Dieckow J, Souza LCDP, Minella JPG, Almeida L De, Ramos MR. 2014. Quality of surface water related to land use: a case study in a catchment with small farms and intensive vegetable crop production in southern Brazil. Revista Brasileira de Ciência do Solo 38 (2): 656-668 DOI: 10.1590/S0100-06832014000200030

Rinaldo A, Vogel GK, Rigon R, Rodriguez-Iturbe I. 1995. Can One Gauge the Shape of a Basin? Water Resources Research 31 (4): 1119-1127 DOI: 10.1029/94WR03290

Rockstrom J, Karlberg L, Wani SP, Barron J, Hatibu N, Oweis T, Bruggeman A, Farahani J, Qiang Z. 2010. Managing water in rainfed agriculture-The need for a paradigm shift. Agricultural Water Management 97 (4): 543-550 DOI: 10.1016/j.agwat.2009.09.009

Rodriguez-Lloveras X, Bussi G, Francés F, Rodriguez-Caballero E, Solé-Benet A, Calle M, Benito G. 2015. Patterns of runoff and sediment production in response to land-use changes in an ungauged Mediterranean catchment. Journal of Hydrology 531: 1054-1066 DOI: $10.1016 /$ j.jhydrol.2015.11.014

Rose CW. 2004. An introduction to the environmental physics of soil, water, and watersheds. Cambridge University Press.

Sidle RC. 2018. Discovery of zero - order basins as an important link for progress in hydrogeomorphology. (July): 3059-3065 DOI: 10.1002/hyp.13246

Soil Conservation Service Engineering Division. 1972. Section 4: Hydrology. In National Engineering Handbook. 
Solyom PB, Tucker GE. 2004. Effect of limited storm duration on landscape evolution, drainage basin geometry, and hydrograph shapes. Journal of Geophysical Research 109 (F3) DOI: 10.1029/2003jf000032

Takken I, Jetten V, Govers G, Nachtergaele J, Steegen A. 2001. The effect of tillage-induced roughness on runoff and erosion patterns. Geomorphology 37 (1-2): 1-14 DOI: 10.1016/S0169-555X(00)00059-3

Tedela NH, McCutcheon SC, Rasmussen TC, Hawkins RH, Swank WT, Campbell JL, Adams MB, Jackson CR, Tollner EW. 2012. Runoff Curve Numbers for 10 Small Forested Watersheds in the Mountains of the Eastern United States. Journal of Hydrologic Engineering 17 (11): 1188-1198 DOI: 10.1061/(ASCE)HE.1943-5584.0000436

Tiecher T, Minella JPG, Caner L, Evrard O, Zafar M, Capoane V, Le Gall M, Santos DR dos. 2017. Quantifying land use contributions to suspended sediment in a large cultivated catchment of Southern Brazil (Guaporé River, Rio Grande do Sul). Agriculture, Ecosystems and Environment 237: 95-108 DOI: 10.1016/j.agee.2016.12.004

Do Valle Junior LCG, Rodrigues DBB, de Oliveira PTS. 2019. Initial abstraction ratio and Curve Number estimation using rainfall and runoff data from a tropical watershed. Revista Brasileira de Recursos Hidricos 24 (0) DOI: 10.1590/2318-0331.241920170199

de Vente J, Poesen J, Verstraeten G, Govers G, Vanmaercke M, Van Rompaey A, Arabkhedri M, Boix-Fayos C. 2013. Predicting soil erosion and sediment yield at regional scales: Where do we stand? Earth-Science Reviews 127: 16-29 DOI: 10.1016/j.earscirev.2013.08.014

Williams JD, Wuest SB, Long DS. 2014. Soil and water conservation in the Pacific Northwest through no - tillage and intensified crop rotations. Jouranl of Soil and Water Conservation 69 (6): 495-504 DOI: 10.2489/jswc.69.6.495

WRB. 2014. World Reference Base for Soil Resources 2014, update 2015. International soil classification system for naming soils and creating legends for soil maps. World Soil Resources Reports No. 106. DOI: 10.1017/S0014479706394902

Zuazo VHD, Pleguezuelo CRR, Peinado FJM, de Graaff J, Martínez JRF, Flanagan DC. 2011. Environmental impact of introducing plant covers in the taluses of terraces: Implications for mitigating agricultural soil erosion and runoff. Catena 84 (1-2): 79-88 DOI: 10.1016/j.catena.2010.10.004 
Table 1. Soil, plant and water managements (treatments) used in each catchment and macroplot.

\begin{tabular}{lllll}
\hline Macroplots & $\begin{array}{l}\text { Soil } \\
\text { management }\end{array}$ & $\begin{array}{l}\text { Crop } \\
\text { management }\end{array}$ & $\begin{array}{l}\text { Runoff } \\
\text { management* }^{*}\end{array}$ & Abbreviation \\
\hline M1 & With chisel & Low phytomass & Without & CLF \\
M2 & Without chisel & Low phytomass & Without & NCLF \\
M3 & With chisel & High phytomass & Without & CHF \\
M4 & Without chisel & High phytomass & Without & NCHF \\
\hline Catchments & & & & \\
\hline C1 & Without chisel & Low phytomass & Without & NTC \\
C2 & Without chisel & Low phytomass & With & TC \\
\hline
\end{tabular}

*Broad-based terraces 
Table 2. Characteristic variables obtained in the analysis of hyetograms and hydrograms.

\begin{tabular}{|c|c|c|}
\hline Abbreviation & Description & Unit \\
\hline $\mathrm{P}$ & Rainfall & $\mathrm{mm}$ \\
\hline $\mathrm{R}_{10}, \mathrm{R}_{30}$ e $\mathrm{R}_{60}$ & Maximum rainfall intensity at 10,30 and 60 minute intervals & $\mathrm{mm} \mathrm{h}^{-1}$ \\
\hline $\mathrm{RP}$ & Return period & years \\
\hline $\mathrm{RC}$ & Runoff coefficient & $\%$ \\
\hline Q & Runoff & $\mathrm{mm}$ \\
\hline $\mathrm{Q}_{\text {peak }}$ & Peak flow & $\mathrm{L} \mathrm{s}^{-1}$ \\
\hline TLP & Time between the beginning of rainfall and peak flow & $\min$ \\
\hline TLPC & Time between the hyetogram centroid and the peak flow & $\min$ \\
\hline TLC & Time between the hyetogram centroid and the hydrogram centroid & $\min$ \\
\hline TLR & Time between the beginning of rainfall and start of runoff & $\min$ \\
\hline $\mathrm{T}_{\mathrm{C}}$ & Time of concentration & $\min$ \\
\hline
\end{tabular}


Table 3. Major monitored rainfall events classified by decreasing return periods.

\begin{tabular}{lccc}
\hline Date & P $(\mathbf{m m})$ & TDP $(\mathbf{m i n})$ & RP (years) \\
\hline $05 / 13 / 2017$ & 105 & 102 & 115.38 \\
$02 / 10 / 2018$ & 93 & 86 & 67.43 \\
$10 / 08 / 2015$ & 160 & 774 & 43.66 \\
$11 / 19 / 2015$ & 73 & 66 & 19.82 \\
$10 / 18 / 2016$ & 111 & 306 & 16.07 \\
$03 / 15 / 2018$ & 82 & 121 & 11.22 \\
$01 / 27 / 2018$ & 61 & 69 & 4.34 \\
$06 / 07 / 2017$ & 116 & 1012 & 2.1 \\
$12 / 23 / 2015$ & 79 & 230 & 2.05 \\
$11 / 03 / 2014$ & 51 & 56 & 1.86 \\
$08 / 13 / 2017$ & 80 & 294 & 1.35 \\
$10 / 30 / 2014$ & 69 & 192 & 1.04 \\
\hline
\end{tabular}

Where: $\mathrm{P}$ is the total accumulated rainfall; TDP is the rainfall total duration; and $\mathrm{RP}$ is the return period. 


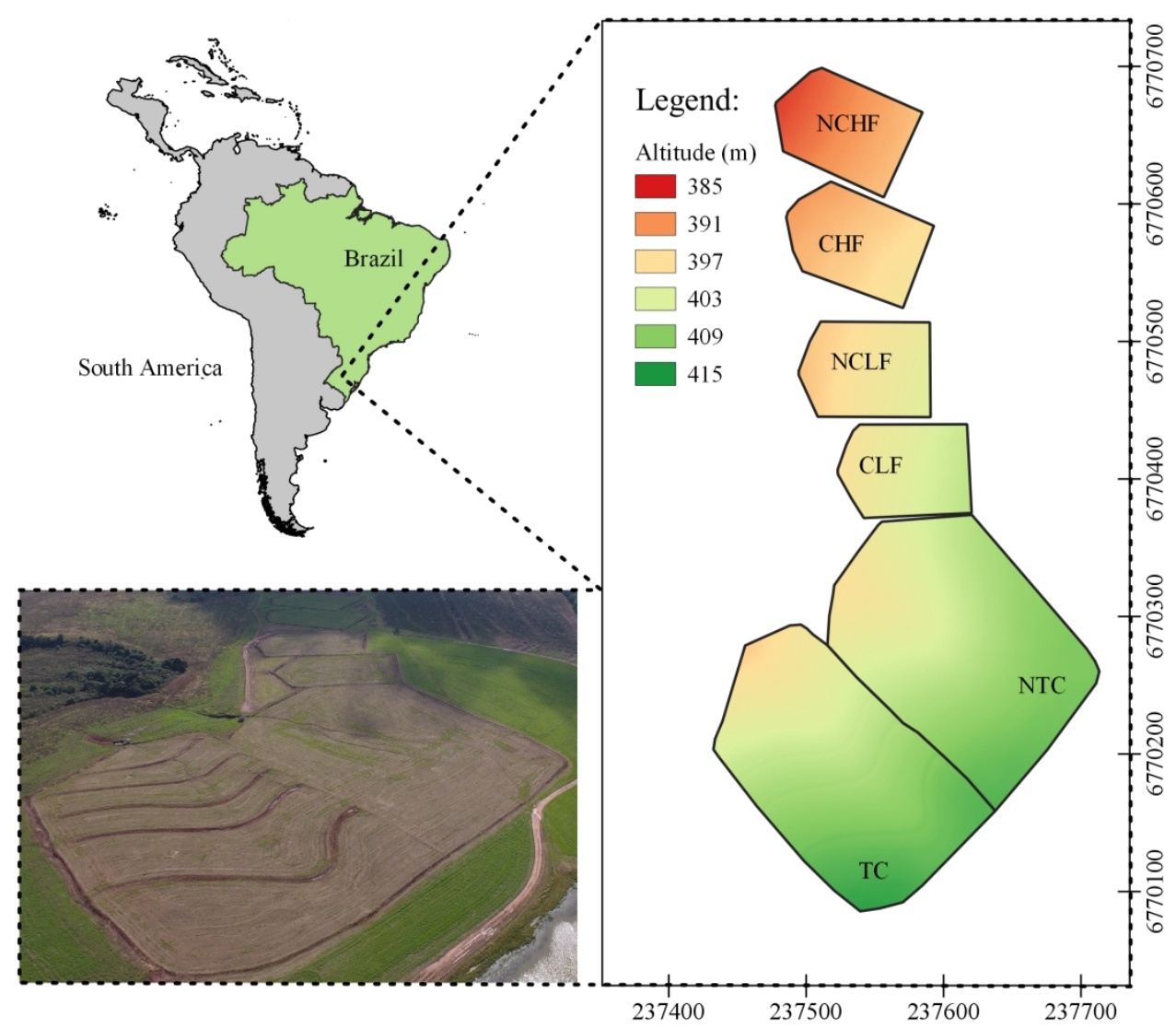

Figure 1. Location of the experimental area and six monitoring units. 


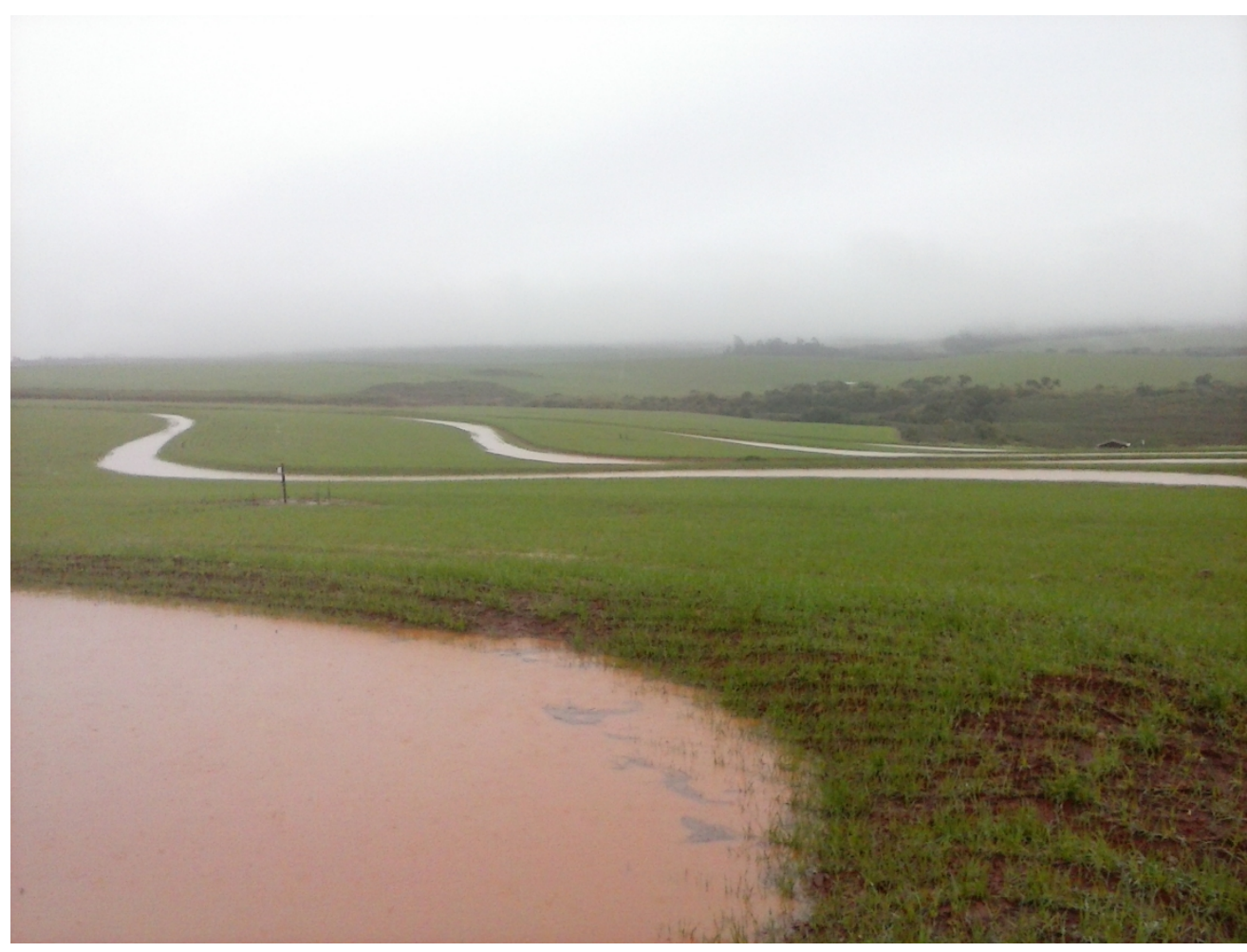

Figure 2. The terraces controlling the runoff after a rainfall event. 


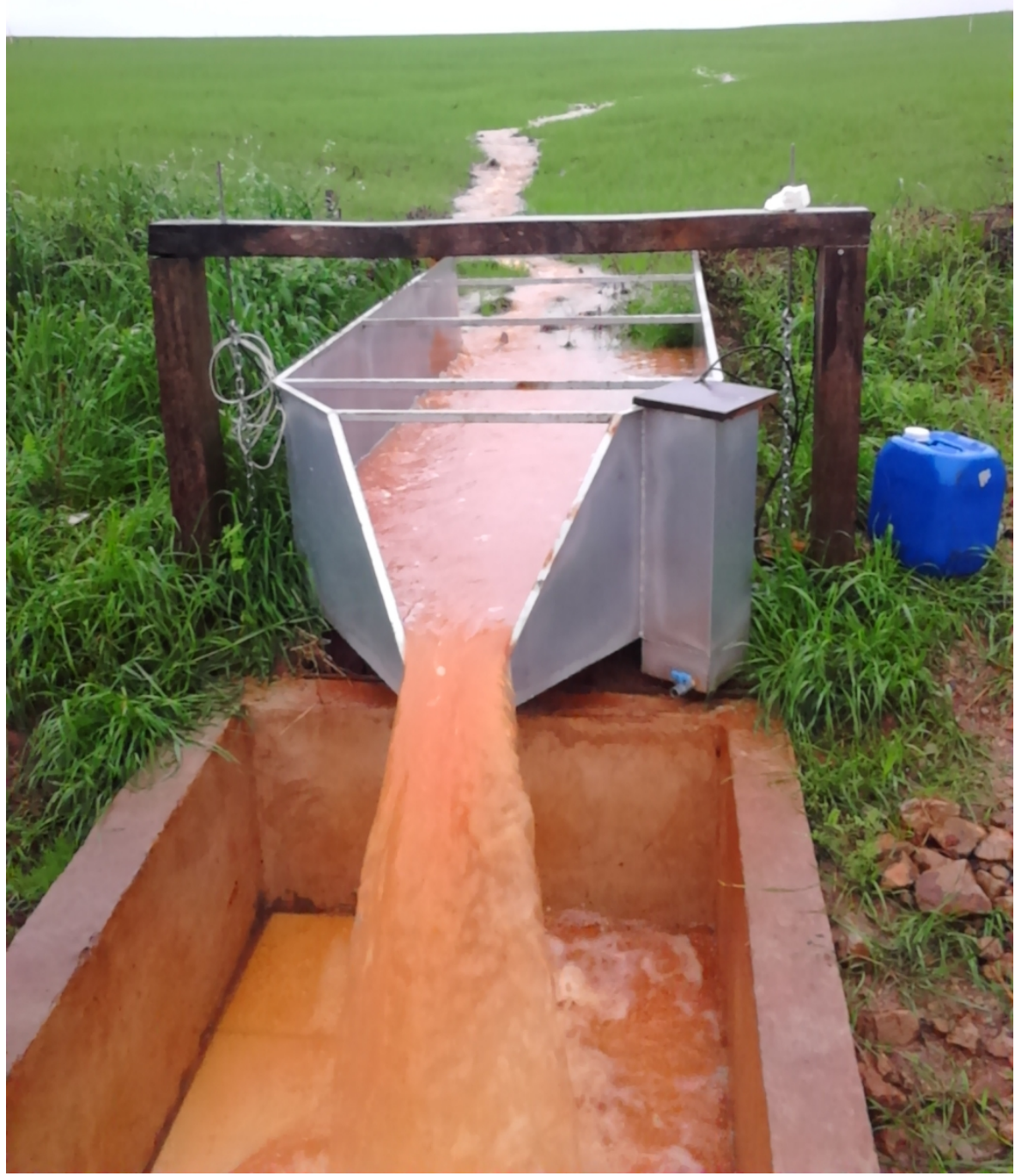

Figure 3. H-flume for monitoring the flow rates installed in the lower part of the catchments and macroplots. 


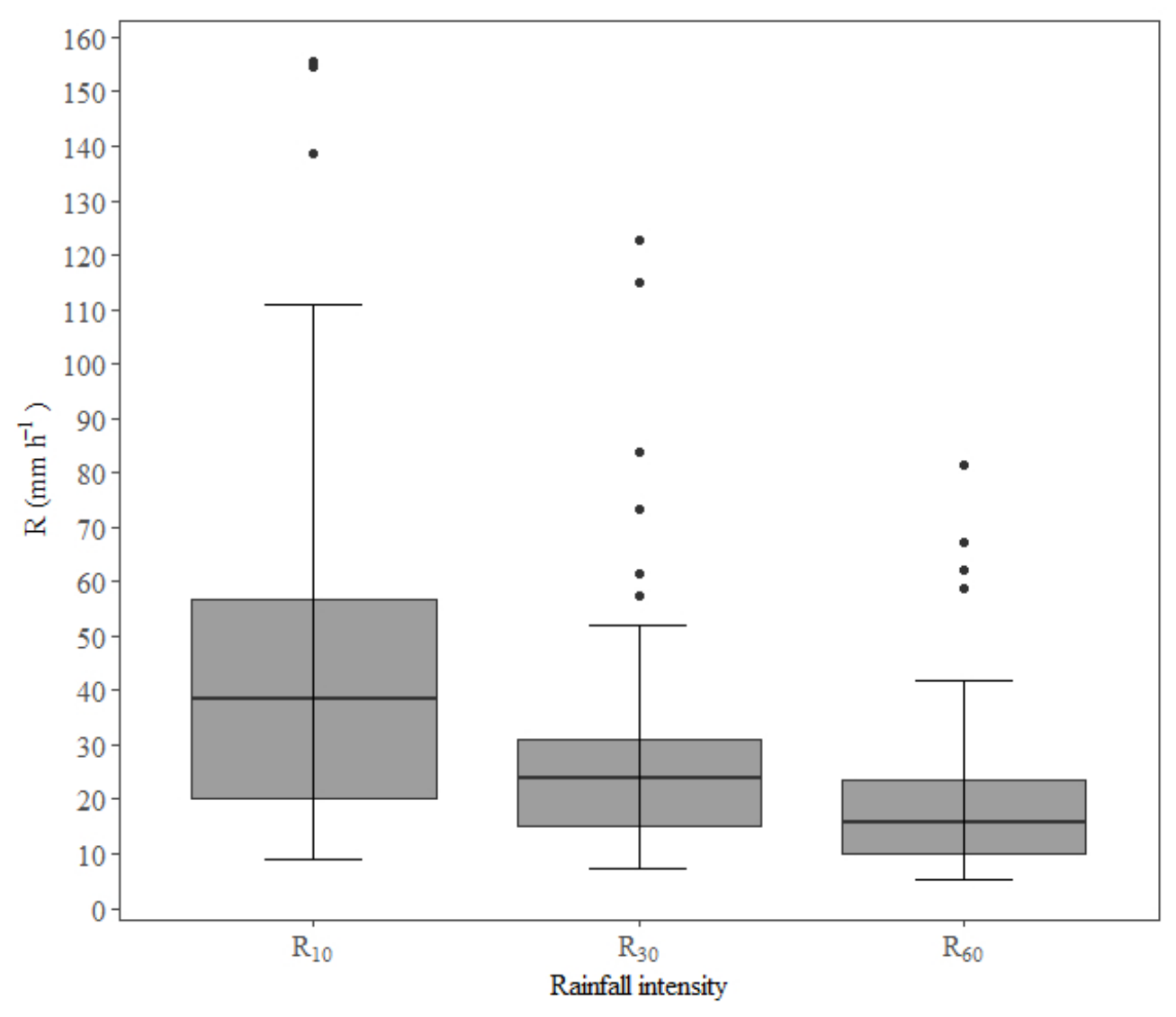

Figure 4. Rainfall intensity for 10, 30, and 60-min intervals. 


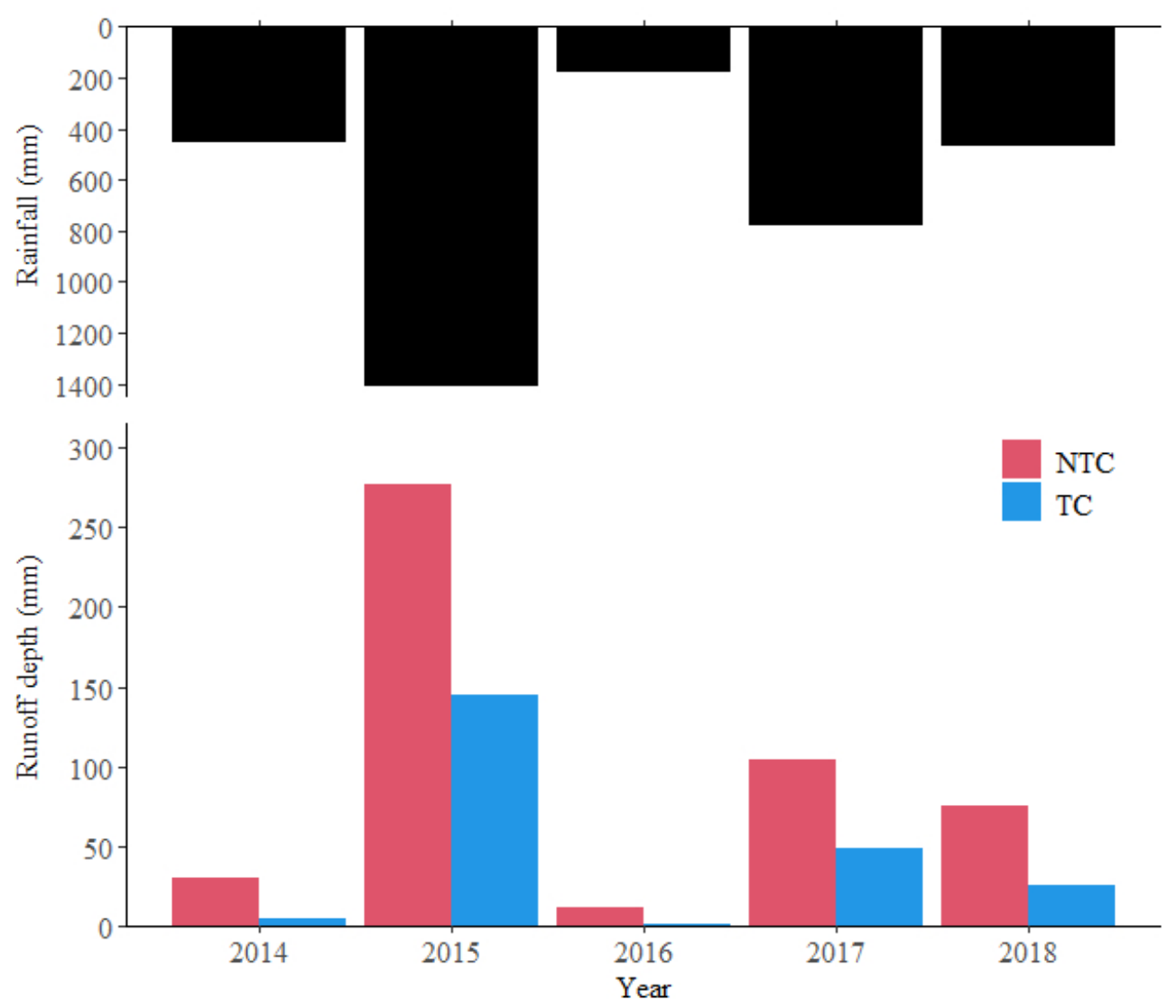

Figure 5. Rainfall and total runoff volume in the NTC and TC during rainfall events. 


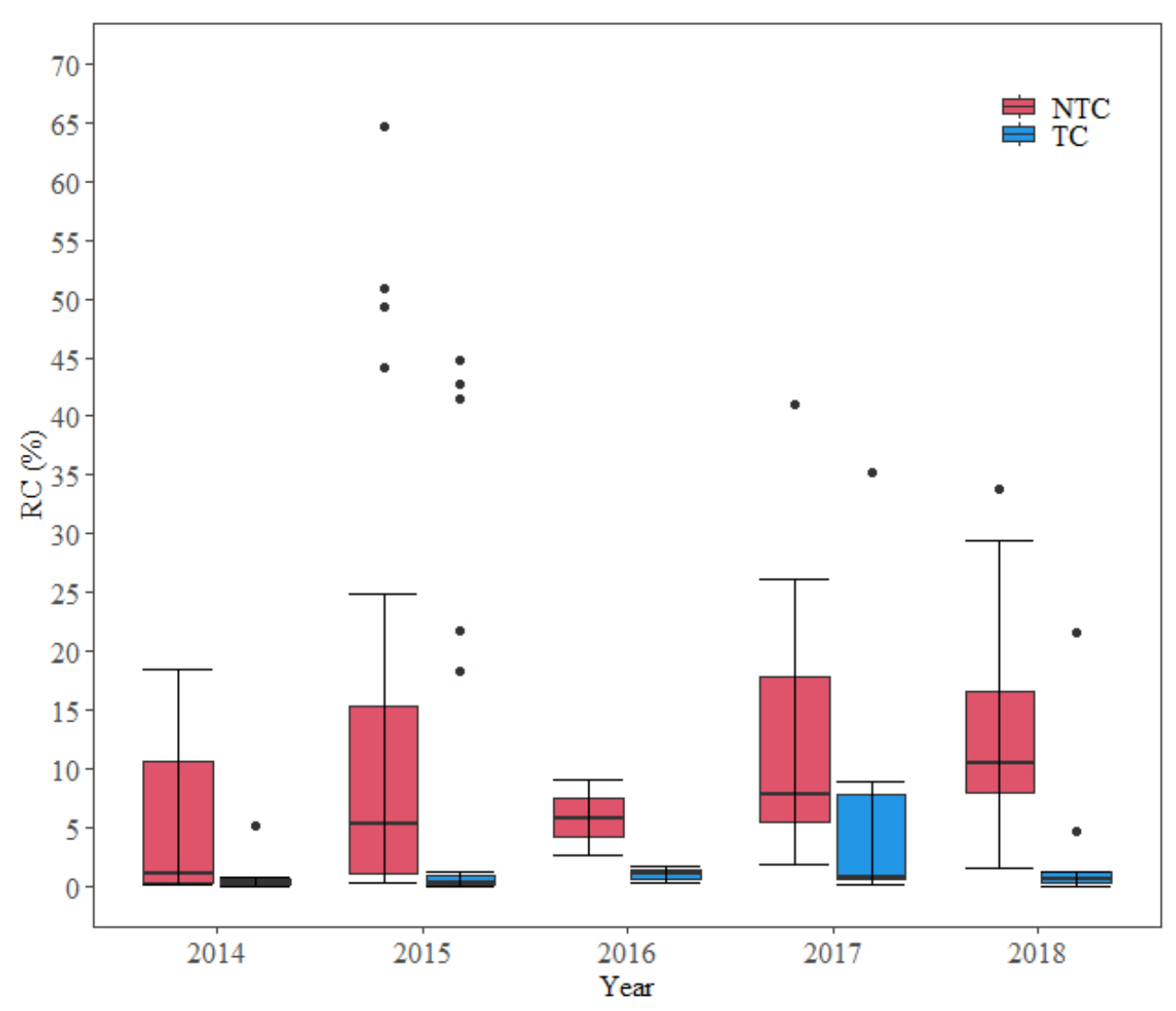

Figure 6. Values of runoff coefficient (RC) in the NTC and TC. 


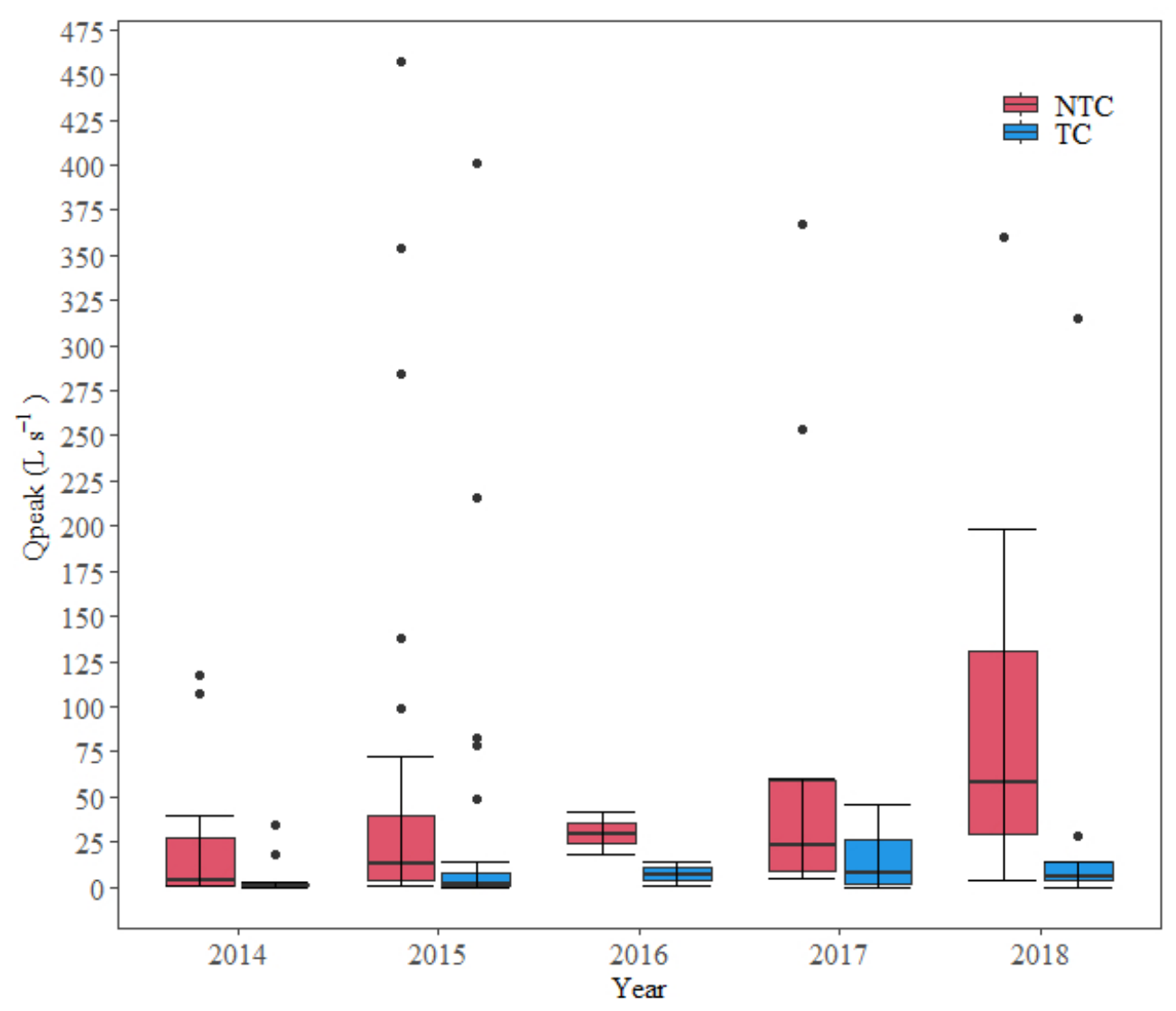

Figure 7. Differences in peak flow (Qpeak) between the NTC and TC. 


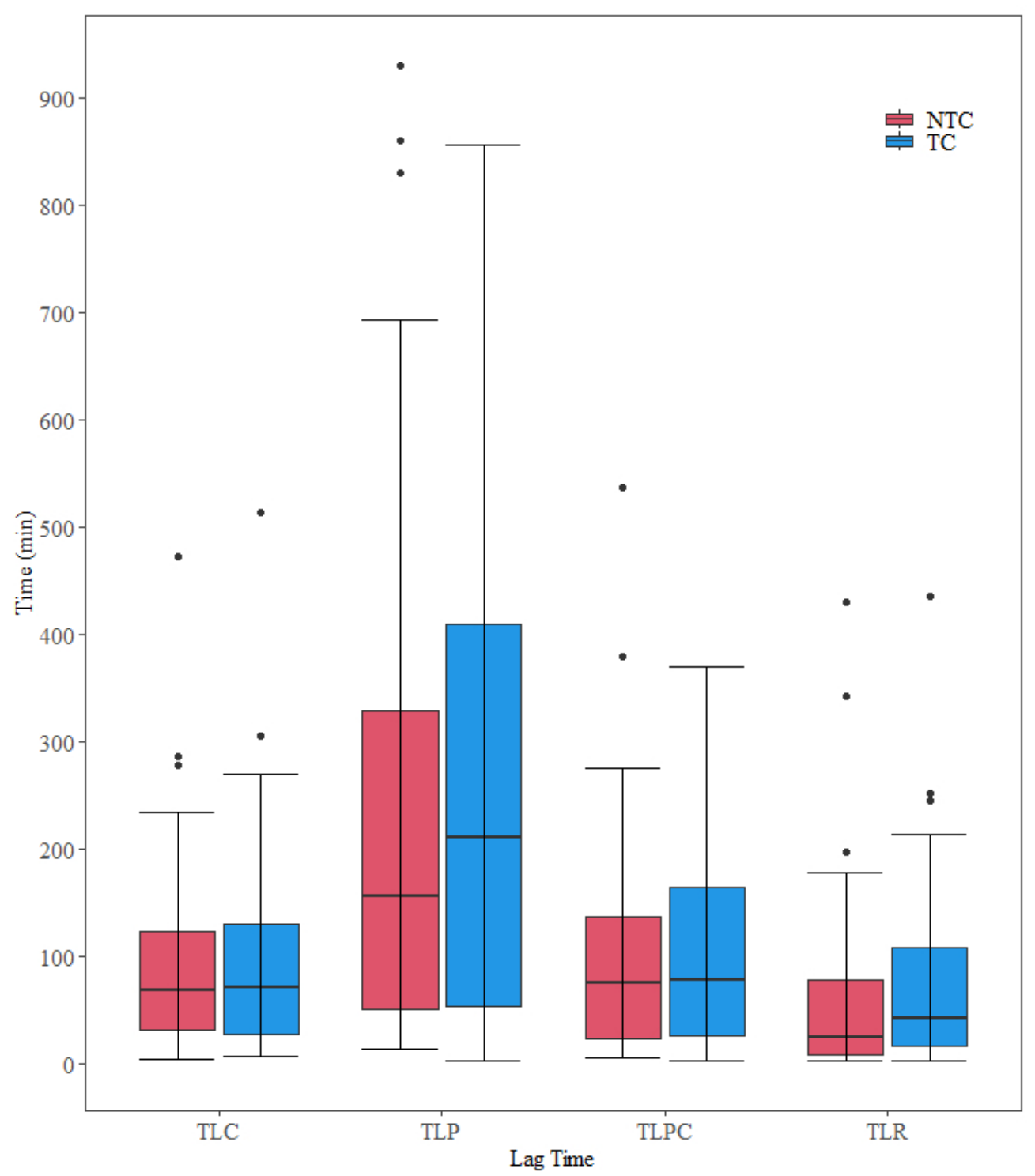

Figure 8. The behavior of three Lag Time variables (TLC, TLP, TLPC, and TLR) for the set of events monitored at NTC and TC. 


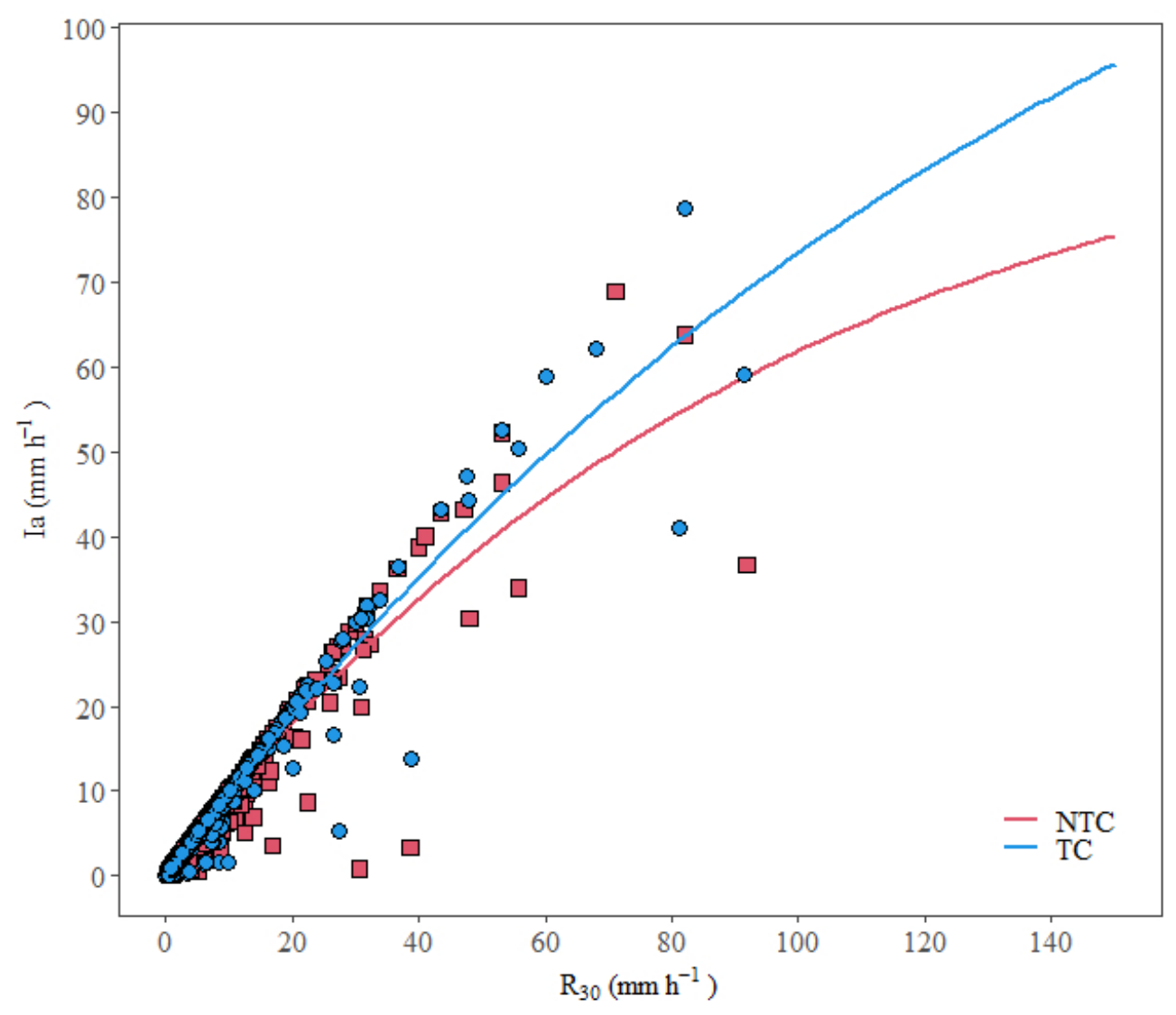

Figure 9. Total apparent infiltration model for 30-min rainfall intensities at the NTC and TC. 


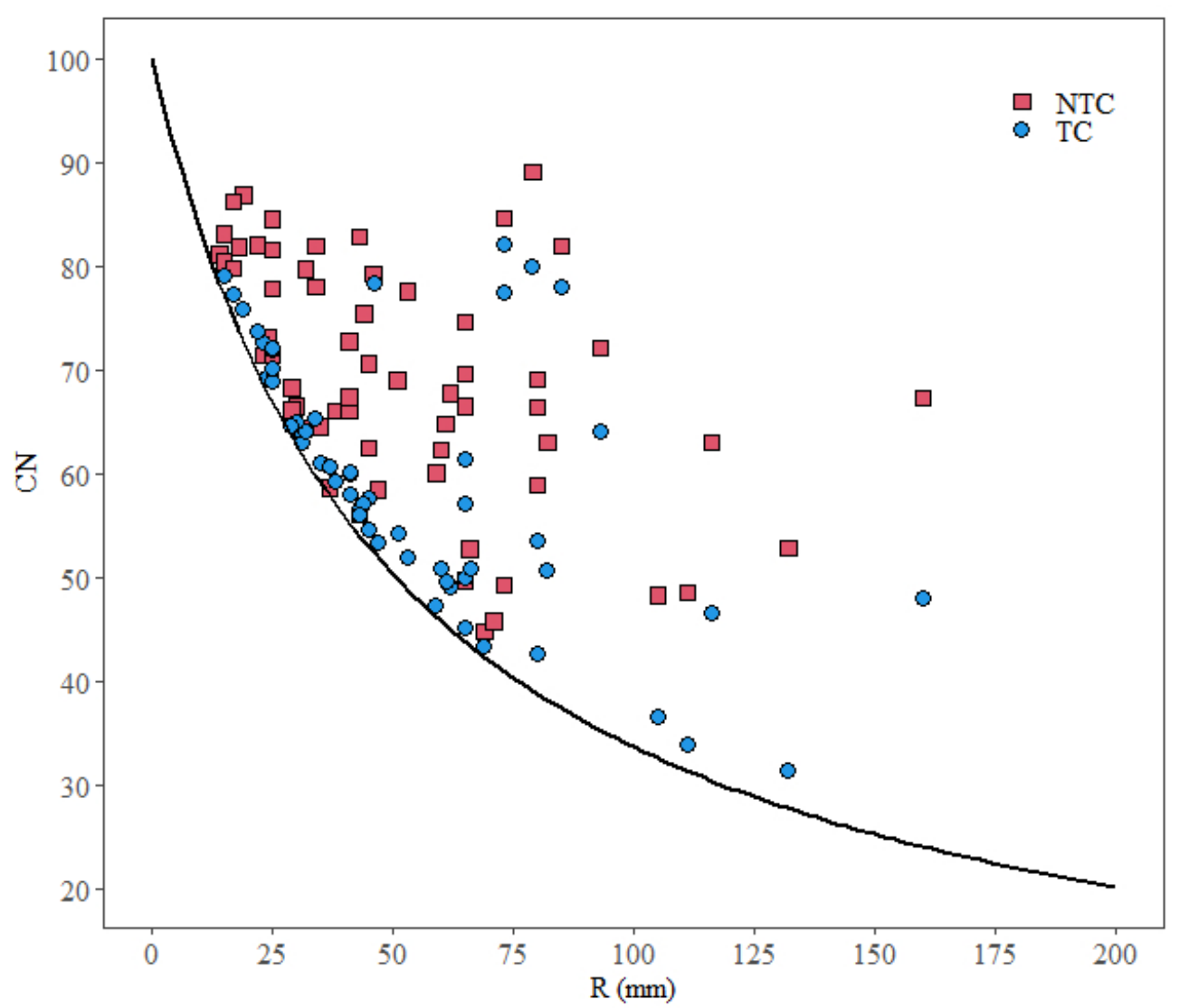

Figure 10. CN values as a function of the rainfall that occurred during the monitoring period. 


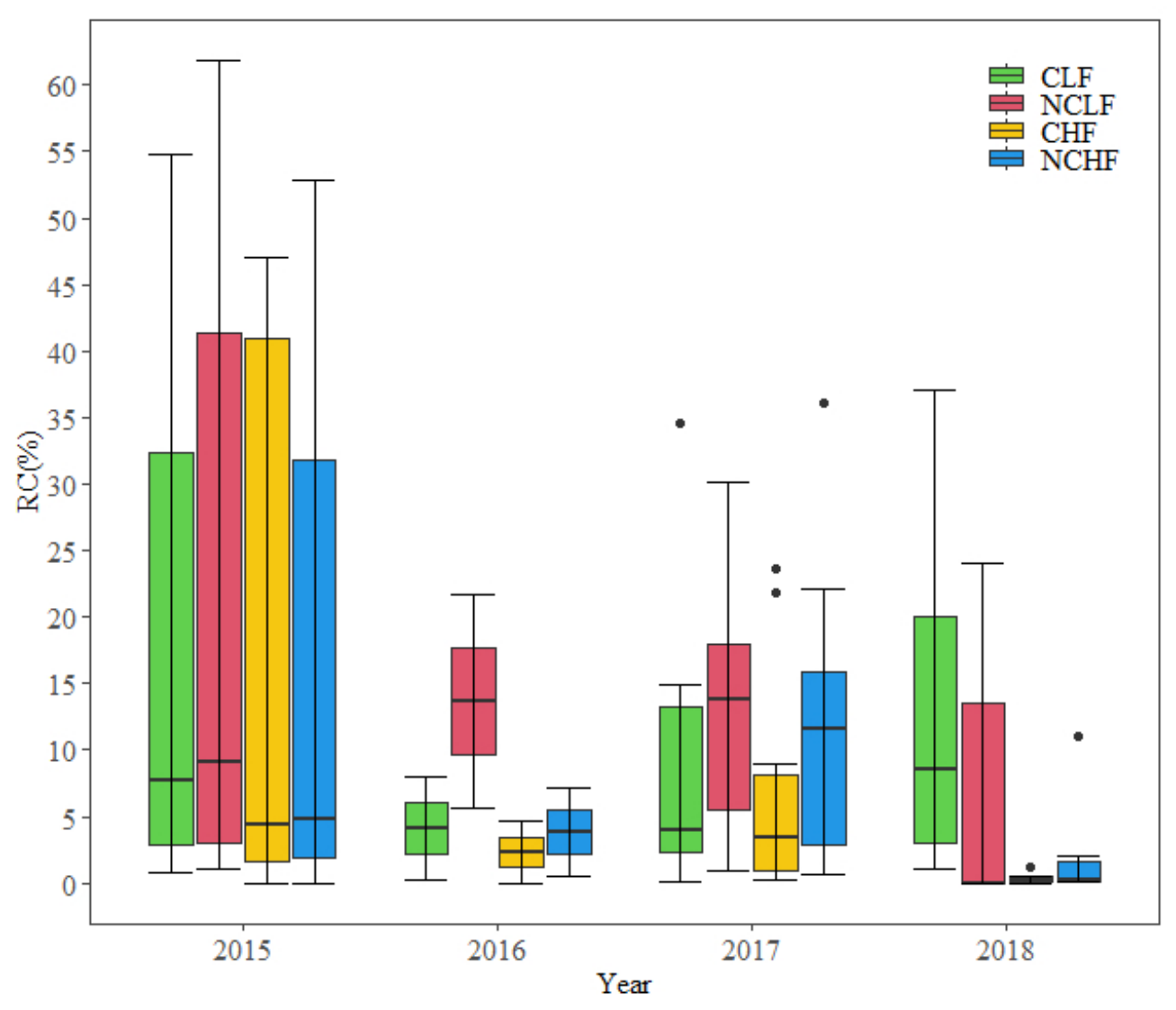

Figure 11. Variation of the runoff coefficient in the macroplots. 


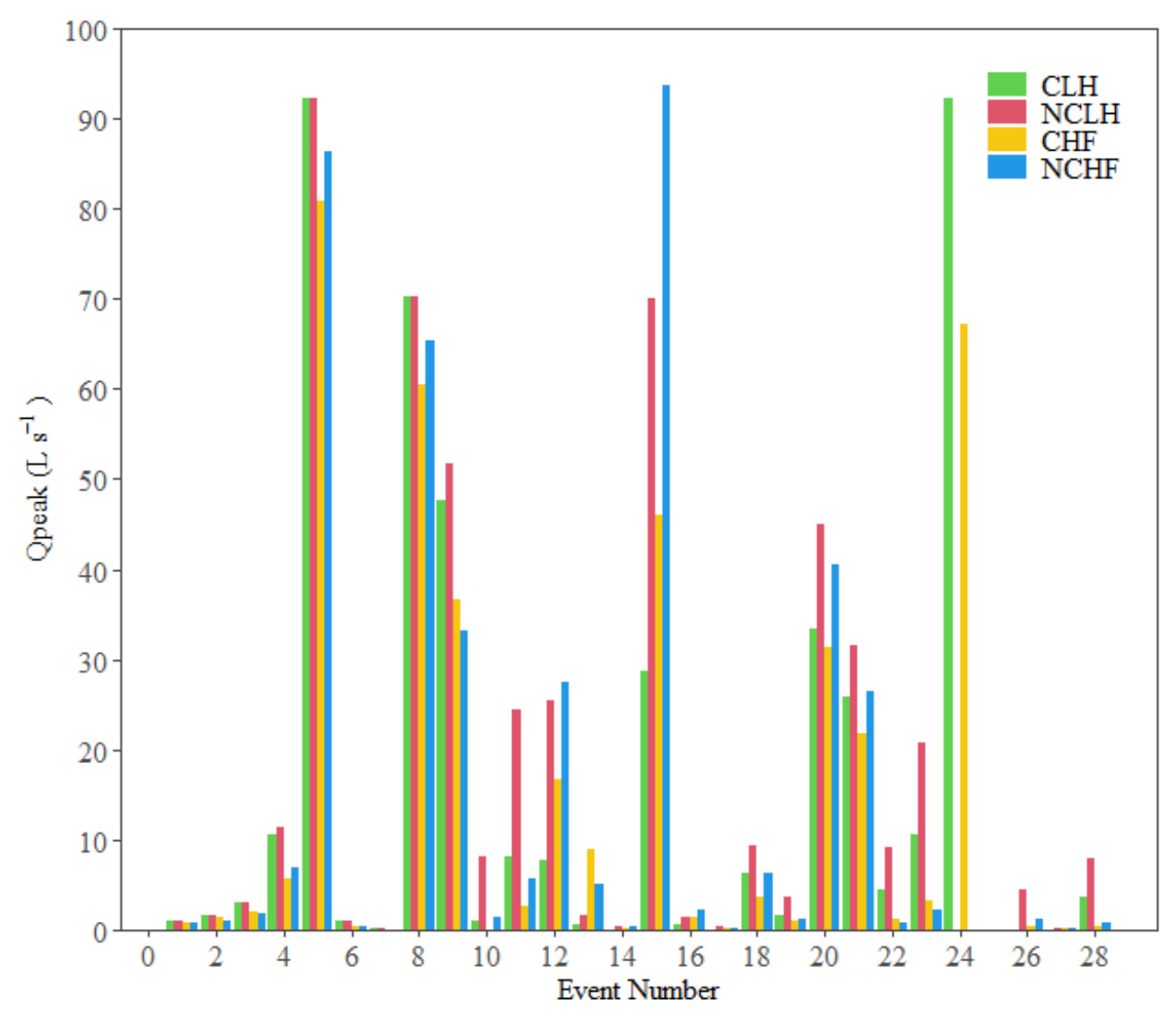

Figure 12. The difference of Qpeak on the events monitored in the four macroplots. 
08/13/2017

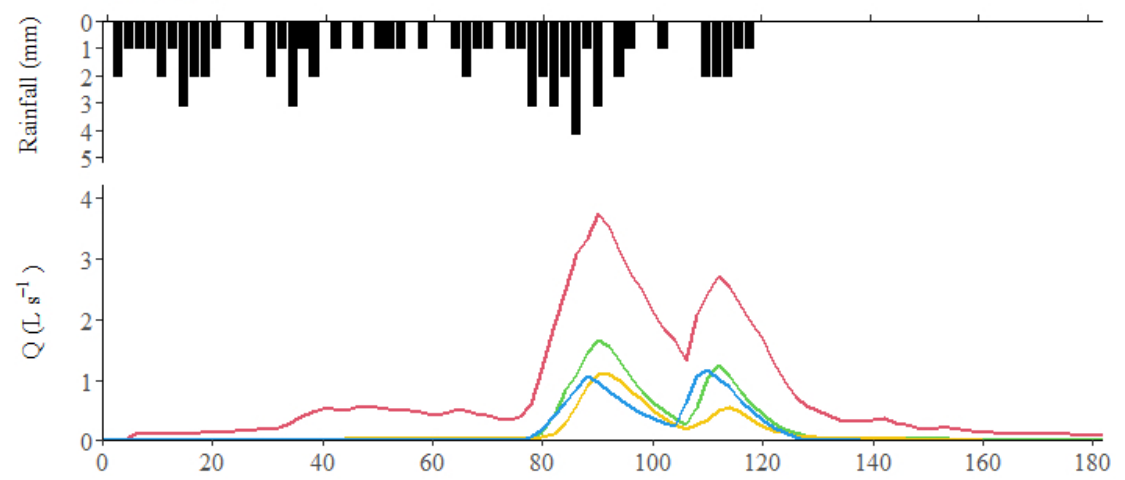

$12 / 24 / 2015$
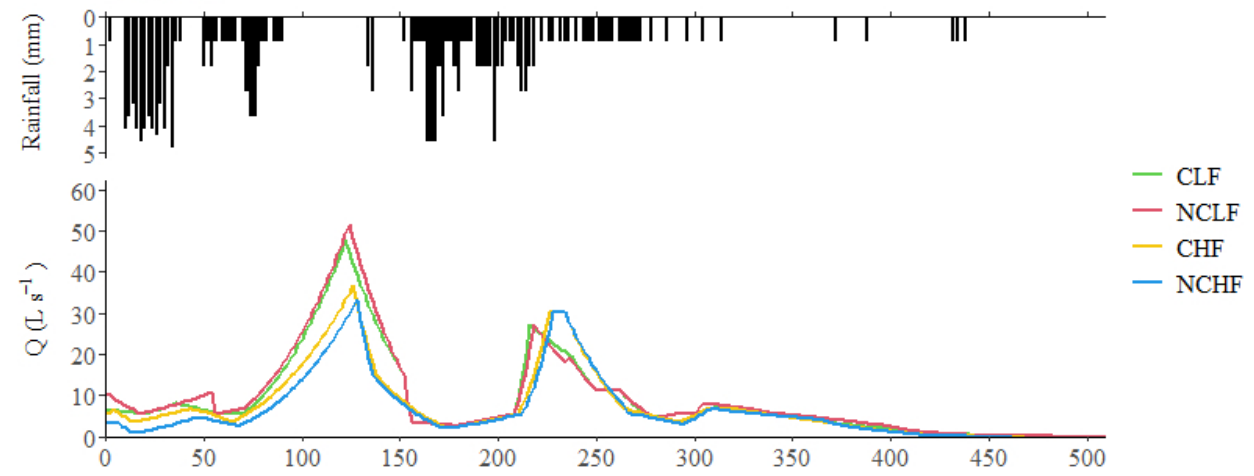

$05 / 26 / 2017$
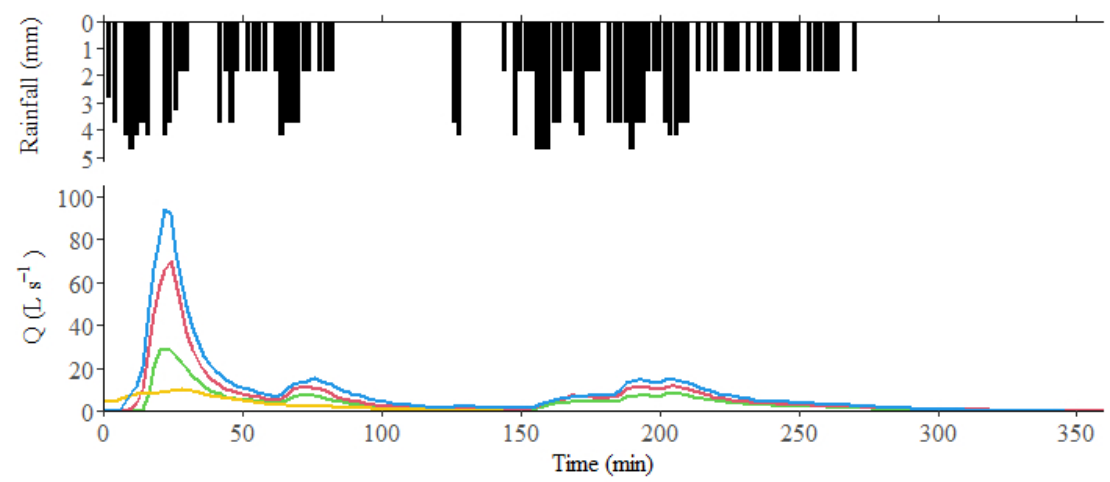

Figure 13. Hyetograph and hydrograph characteristics in the macroplots. 

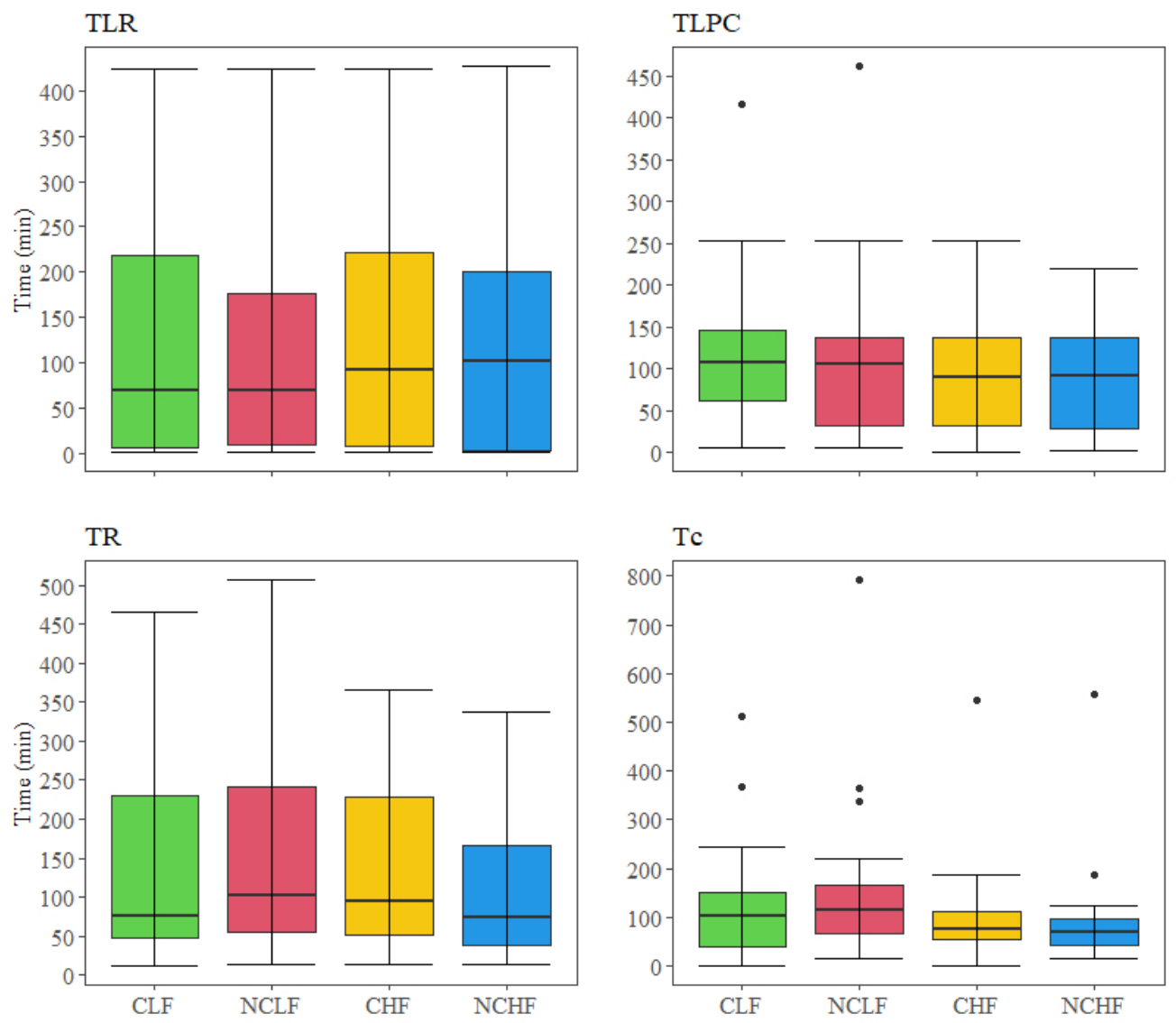

Figure 14. Behavior of time lag variables for the set of events monitored in the macroplots. 


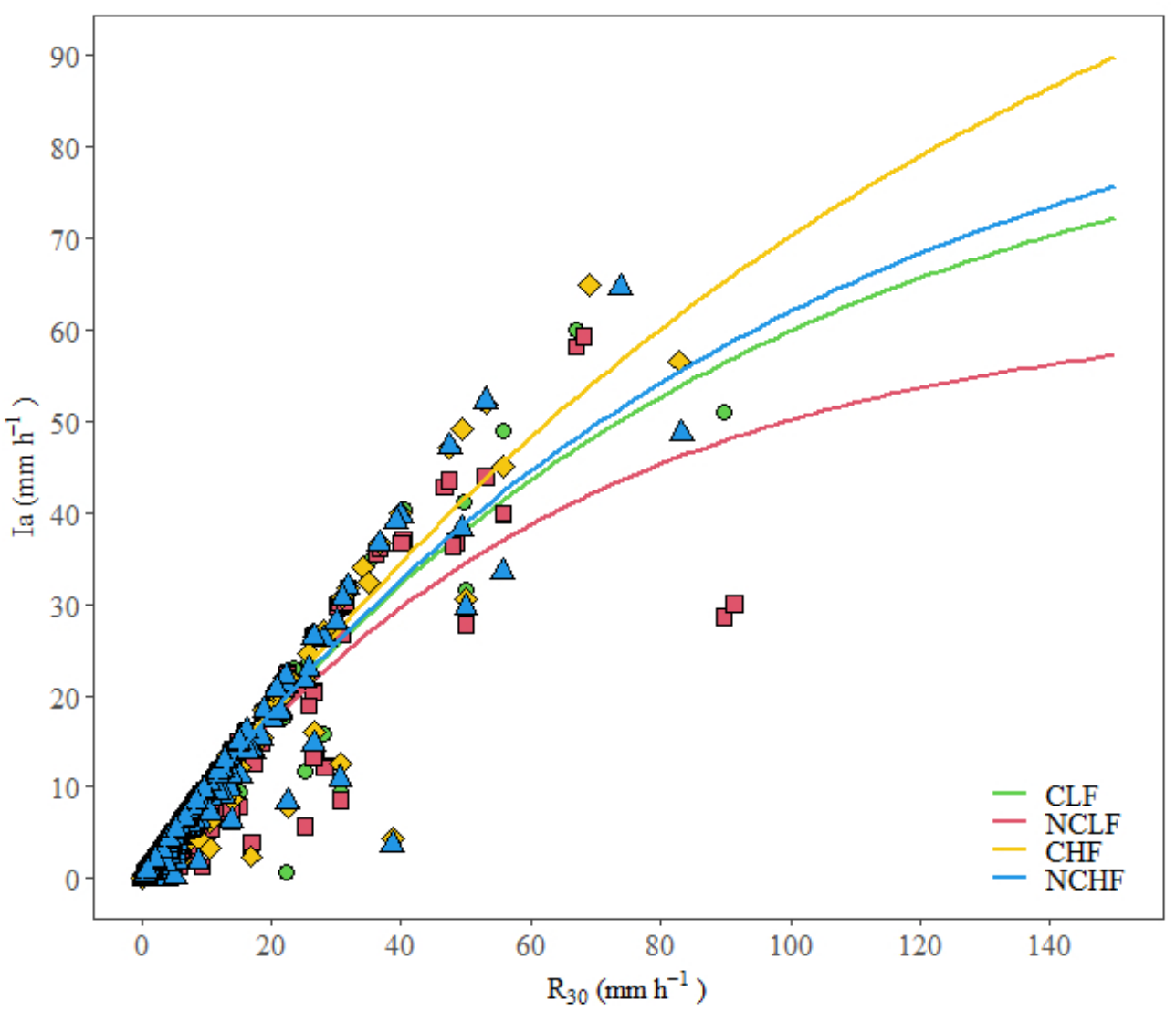

Figure 15. Relationship between the total apparent infiltration and maximum rainfall intensity of 30 min for the macroplots. 


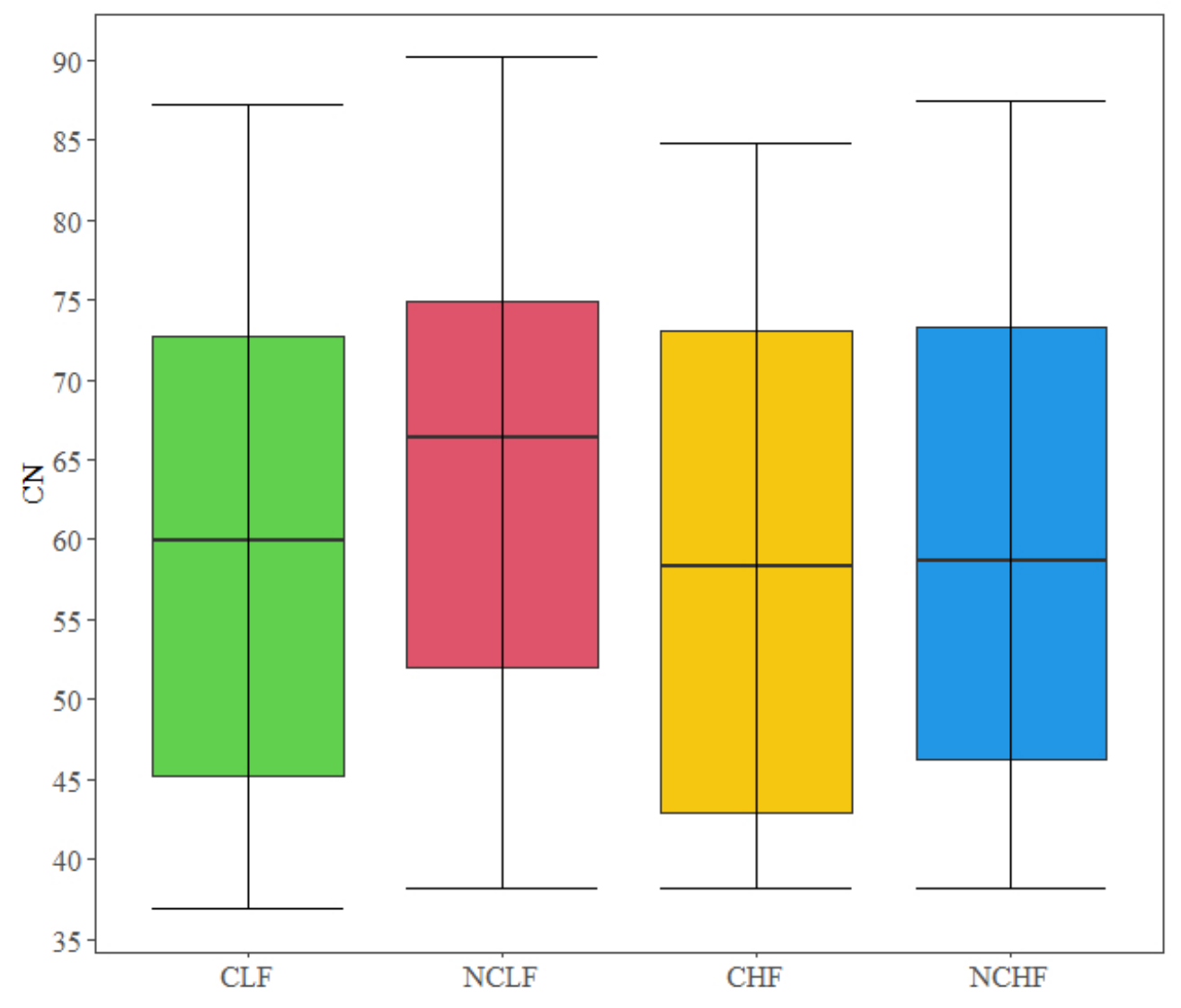

Figure 16. The $\mathrm{CN}$ values estimated for the set of events monitored in the macroplots. 


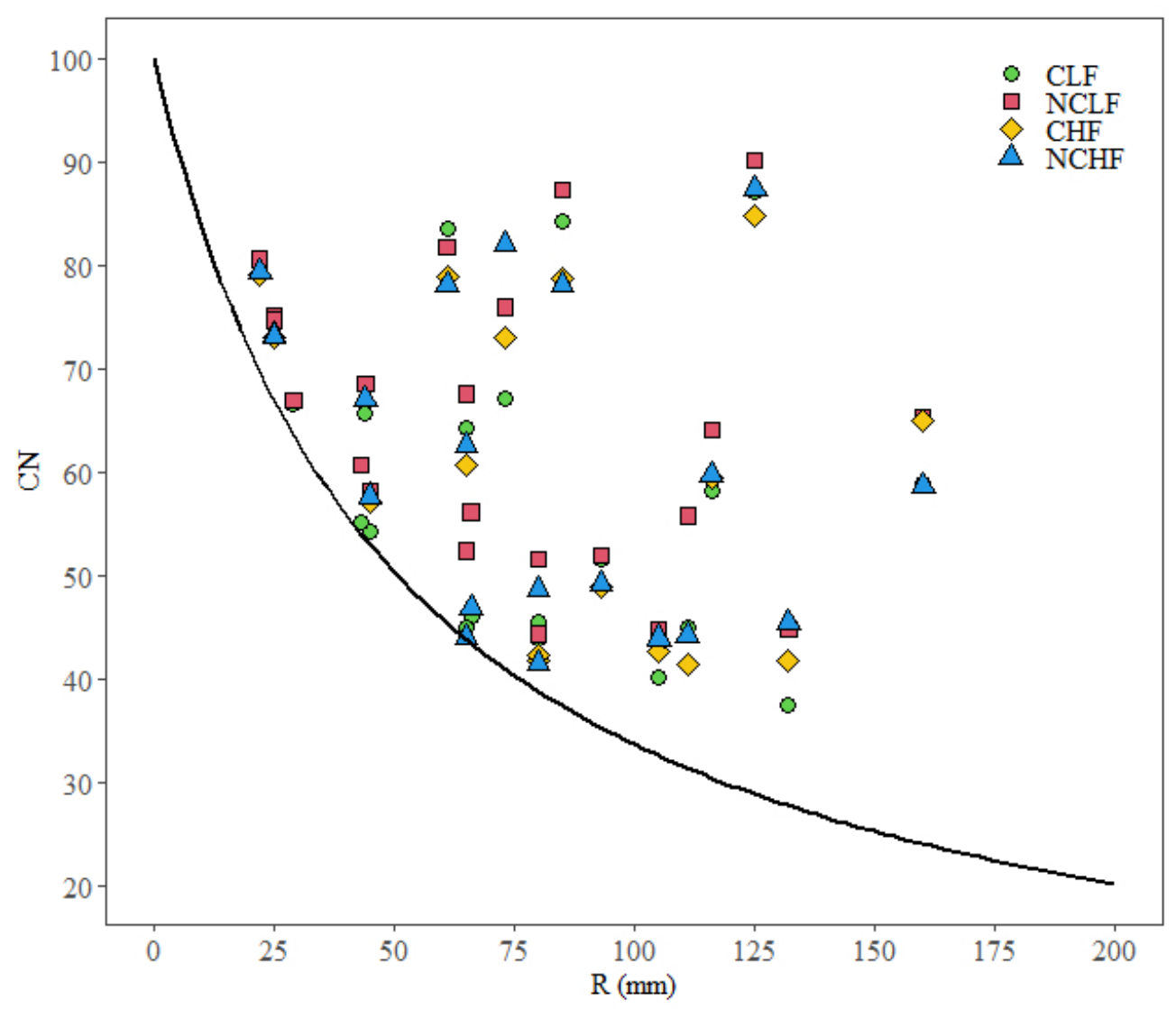

Figure 17. Dispersion of $\mathrm{CN}$ values as a function of rainfall in the macroplots. 
Runoff under No-tillage at Catchment/Hillslope scale
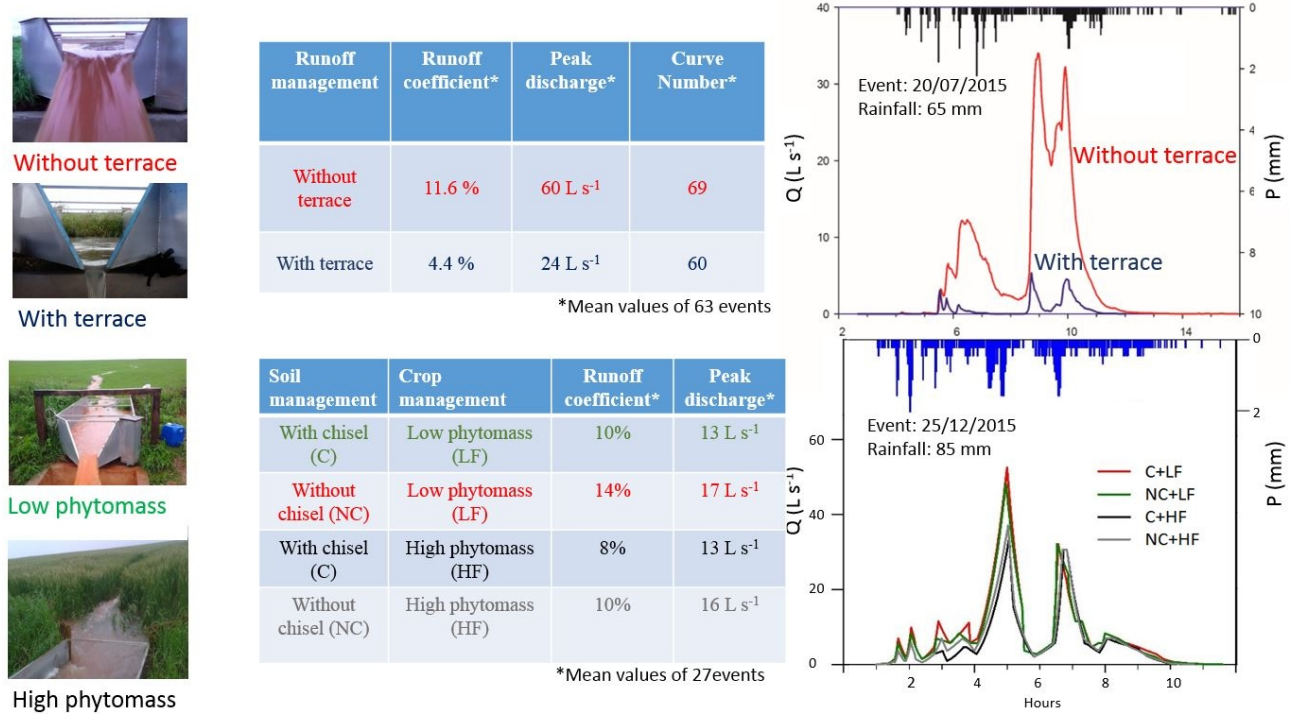

High phytomass

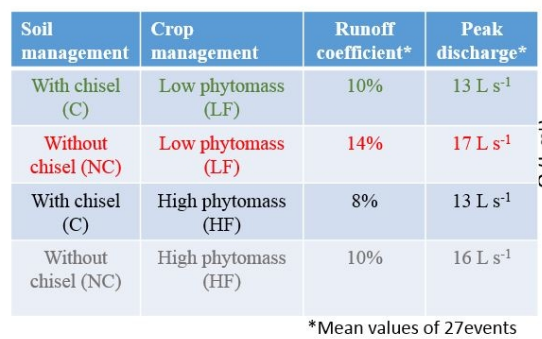

${ }^{*}$ Mean values of 27 event 